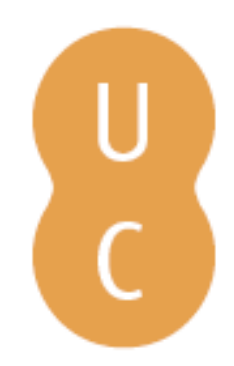

\title{
nombalina
}

\section{Vasos gregos da coleção D. Manuel de Lancastre}

Autor(es): $\quad$ Morais, Rui; Centeno, Rui M. S.

Publicado por: Imprensa da Universidade de Coimbra

URL

persistente: URI:http://hdl.handle.net/10316.2/37186

DOI: $\quad$ DOI:http://dx.doi.org/10.14195/978-989-26-0953-9

Accessed : $\quad$ 26-Apr-2023 11:41:41

A navegação consulta e descarregamento dos títulos inseridos nas Bibliotecas Digitais UC Digitalis, UC Pombalina e UC Impactum, pressupõem a aceitação plena e sem reservas dos Termos e Condições de Uso destas Bibliotecas Digitais, disponíveis em https://digitalis.uc.pt/pt-pt/termos.

Conforme exposto nos referidos Termos e Condições de Uso, o descarregamento de títulos de acesso restrito requer uma licença válida de autorização devendo o utilizador aceder ao(s) documento(s) a partir de um endereço de IP da instituição detentora da supramencionada licença.

Ao utilizador é apenas permitido o descarregamento para uso pessoal, pelo que o emprego do(s) título(s) descarregado(s) para outro fim, designadamente comercial, carece de autorização do respetivo autor ou editor da obra.

Na medida em que todas as obras da UC Digitalis se encontram protegidas pelo Código do Direito de Autor e Direitos Conexos e demais legislação aplicável, toda a cópia, parcial ou total, deste documento, nos casos em que é legalmente admitida, deverá conter ou fazer-se acompanhar por este aviso. 


\section{VASOS GREGOS DA COLEÇÃO D. MANUEL DE LANCASTRE}

RUI MORAIS

RUI M. S. CENTENO

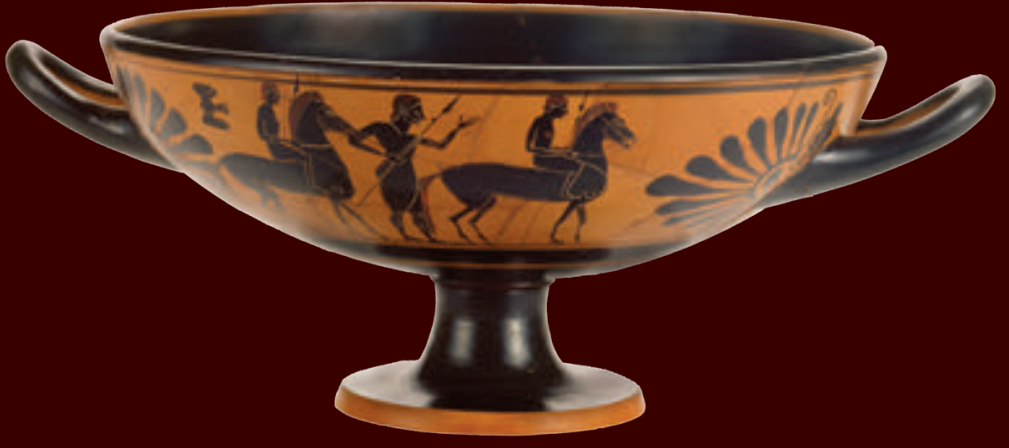


Dando continuidade ao estudo de coleçôes

públicas e privadas subordinado ao tema da arte

grega e de tema clássico (Morais 2011; Jesus 2012)

apresenta-se, nesta série, alguns dos vasos gregos

da coleção de D. Manuel de Lancastre.

Esta coleção, constituída por 31 vasos gregos,

repartidos pelos estilos coríntio e italo-coríntio,

ático de figuras negras e vermelhas e pelos estilos

do sul de Itália de figuras vermelhas que incluem

produçóes apúlias, campanienes e pestenses

e três gutti com relevo, é, como já referimos

(Morais e Centeno, 2013), a mais importante

até à data reunida em Portugal. 
CLASSICA

INSTRVMENTA 



\section{VASOS GREGOS DA COLEÇÃO D. MANUEL DE LANCASTRE}

RUI MORAIS

RUI M. S. CENTENO 
Título • Vasos Gregos da Coleção D. Manuel Lancastre

Autores • Rui Morais e Rui M. S. Centeno

Ficha Técnica

Classica instrVmenta - Monografias de História de Arte e Arqueologia

Coordenador Científico do plano de edição: Maria do Céu Fialho

COMISSÃo REDACTORIAL

José Ribeiro Ferreira

Francisco de Oliveira

Maria de Fátima Silva

Nair Castro Soares

\section{Director TÉCnico: Delfim Leão}

Conselho Editorial

Adolfo Fernández Fernández | Vigo

Amílcar Guerra | Lisboa

Ángel Morillo Cerdán | Madrid

Carlos Fabião | Lisboa

Luísa de Nazaré Ferreira | Coimbra

\section{EDIC̣̃̃O}

Imprensa da Universidade de Coimbra URL: http://www.uc.pt/imprensa_uc

E-mail: imprensa@uc.pt

Vendas online:

http://livrariadaimprensa.uc.pt

\section{CoOrdenaÇão EDITORIAL}

Imprensa da Universidade de Coimbra

ConceÇÃo GRÁFICA

António Barros

INFOGRAFIA

Carlos Costa

Maria Helena da Rocha Pereira | Coimbra Nuno Simões Rodrigues | Lisboa Pedro Carvalho | Coimbra Rui Morais | Braga/Coimbra

Impressão e Acabamento

RealBase

ISBN

978-989-26-0958-4

ISBN DigITAL

978-989-26-0953-9

DOI

http://dx.doi.org/10.14195/978-989-26-0953-9

Depósito Legal

$395553 / 15$

Obra Publicada com o apoio de:

\section{FCT}

Fundação para a Ciência e a Tecnologia

POCI/2010

(C) Julho 2015.

IMPRENSA DA UNIVERSIDADE DE CoImBra

Classica Digitalia Vniversitatis Conimbrigensis (http://classicadigitalia.uc.pt)

Centro de Estudos Clássicos e Humanísticos da Universidade de Coimbra

Reservados todos os direitos. Nos termos legais fica expressamente proibida a reprodução total ou parcial por qualquer meio, em papel ou em edição electrónica, sem autorização expressa dos titulares dos direitos. É desde já excepcionada a utilização em circuitos académicos fechados para apoio a leccionação ou extensão cultural por via de e-learning. 


\section{Sumário}

PREFÁCIO

PREFACE

ESTILO ETRUSCO-CORÍNTIO.

\section{ETRUSCO-CORINTHIAN STYYLE}

(1) Olpe com aletas circulares 13

Olpe with rotelles

(2) Olpe com aletas circulares. 17

Olpe with rotelles

ESTILO ÁTICO DE FIGURAS NEGRAS

AT'TIC BLACK-FIGURE STYLE

(3) Taça de tipo B - Pintor de Lancastre.

Type B Cup • Lancastre Painter

(4) Taça de tipo B • Pintor de Oltos

Cup Type B • Oltos Painter

(5) Taça de tipo $\mathrm{C} \cdot$ Little-Master Band Cup

Type C Cup • Little-Master Band Cup

(6) Ânfora de colo • À maneira do pintor de Antimenes.

Neck-Amphora - Manner of the Antimenes Painter

(7) Skyphos $\bullet$ Heron Class

Skyphos - Heron Class 
AT'TIC RED-FIGURE STYLE

(8) Taça • Grupo de Pezzino...

Cup • Pezzino Group

(9) Taça • Pintor de Villa Giulia.

Cup - Villa Giulia Painter

(10) Lêkythos • Pintor de Bowdoin

Lekythos - Bowdoin Painter

(11) Hýdria • Oficina do Pintor de Meidias

Hydria • Meidias Painter Workshop

ESTILO APÚLIO DE FIGURAS VERMELHAS

APULIAN RED-FIGURE STYLE

(12) Kratêr-de-sino • Pintor de Dijon.

Bell-Krater • Dijon Painter

(13) Chous • Pintor de Reckoning

Chous • Reckoning Painter

(14) Taça sem pé (Xenon Group) • Pintor do Cisne Rubro 77

Stemless Cup (Xenon Group) • The Red-Swan Painter

(15) Taça sem pé (Xenon Group) • Pintor do Cisne Rubro .79

Stemless Cup (Xenon Group) • The Red-Swan Painter

BIBLIOGRAFIA

BIBLIOGRAPHY

LISTA DE FIGURAS. 


\section{PREFÁCIO \\ PREFACE}


(Página deixada propositadamente em branco) 


\section{PREFÁCIO}

Dando continuidade ao estudo de coleções públicas e privadas subordinado ao tema da arte grega e de tema clássico (Morais 2011; Jesus 2012) apresenta-se nesta série Classica Instrumenta alguns vasos gregos da coleção de D. Manuel de Lancastre. Constituída por 31 vasos gregos, repartidos pelos estilos coríntio e etrusco-coríntio, ático de figuras negras e vermelhas e pelos estilos do sul de Itália de figuras vermelhas que incluem produções apúlias, campanienes e pestenses e três gutti com relevo, esta coleção é, como já referimos (Morais e Centeno, 2013), até à data a mais importante reunida em Portugal.

De entre os exemplares de maior valor artístico e documental destaca-se uma pelike de figuras vermelhas assinada pelo pintor de Brygos, publicada na obra comissariada por Maria Helena da Rocha

\section{PREFACE}

Giving continuity to the study of public and private collections of Greek art and classical themes (Morais, 2011; Jesus, 2012), this series of Classica Instrumenta presents some Greek vases from the D. Manuel of Lancastre collection. The collection comprises 31 Greek vases, of the Corinthian and Etrusco-Corinthian styles, the black- and red-figure Attic style and of the red-figure southern Italian style, which includes Apulian, Campanian and Paestan productions and three embossed gutti. As we have already mentioned (Morais and Centeno, 2013), this collection is to date the most important one in Portugal.

Amongst the vases with greater artistic and documental value, particularly noteworthy is a red-figure pelike, signed by the Brygos Painter, having already been published in a book curated by Maria 
Pereira, Vasos Gregos em Portugal. Aquém das Colunas de Hércules (2007: 92-93).

No presente trabalho estudam-se quinze vasos, dois etrusco-Coríntios, cinco de figuras negras e oito de figuras vermelhas, repartidos por sete taças, um lêkythos, uma ânfora, um skyphos, um krâter-desino e um chous, que já foram objeto de estudo em anteriores publicações (VGPortugal e Morais e Centeno 2013).

Helena da Rocha Pereira, 'Vasos Gregos em Portugal. Aquém das Colunas de Hércules' (2007: 92-93).

In this work, fifteen vases are analyzed, two Etrusco-Corinthian, five black-figured and eight red-figured, of which seven are cups, one lekythos, one amphora, one skyphos, one bell-krater and one chous, that had already been studied in previous publications (VGPortugal and Morais and Centeno 2013). 


\section{ESTILO ETRUSCO-CORÍNTIO ETRUSCO-CORINTHIAN STYLE}




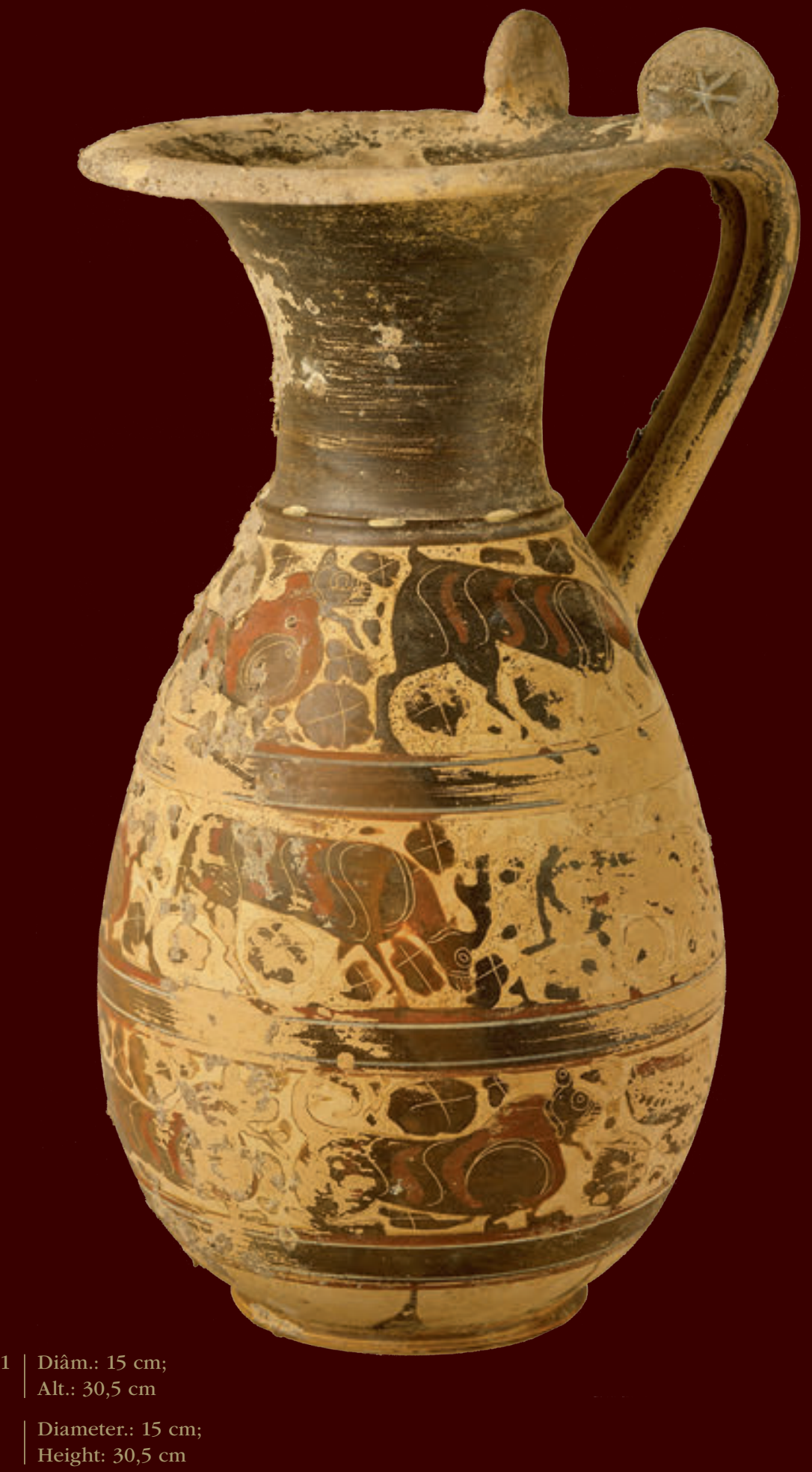


Olpe com aletas circulares • C. 580-560 a.C..

Olpe com parede integralmente decorada com três frisos, separados por bandas com filetes e coroa radial junto à base. Apresenta uma superfície coberta por uma pintura delida, acastanhada escura, decorada com motivos animais pintados a vermelho e a acastanhado escuro, delineados por incisões. Os animais, desenhados de acordo com o designado "estilo alongado", estão representados por cabras monteses, veados, leões e cisnes. Sobre o fundo bege e também realçadas por incisões, numerosas rosetas de cor acastanhada. Assinalada por duas aletas circulares decoradas com rosetas discoidais e lobadas, a asa arranca do lábio e repousa junto à parte superior da parede.

Como é próprio dos produtos de Vulci, está presente o estilo orientalizante, de tradição coríntia, caraterizado pela representação de

Olpe with rotelles • c. 580-560 B.C.

Olpe with totally decorated wall, with three friezes, separated by bands with fillets and a radial crown near the base. Its surface is covered with a dark, brownish faded painting, decorated with animal motifs painted red and dark brown, outlined by incisions. The animals, drawn according to the "elongated style", are mountain goats, deer, lions and swans. There are numerous brownish rosettes on the beige background, also highlighted by incisions. The handle starts from the rim and finishes near the upper part of the wall and is marked by two circular lateral wings decorated with discoid and lobed rosettes.

As is proper of Vulci products, the orientalizing style is present, of Corinthian tradition, characterized by the representation of animals in monotonous lines. By the decorative style and in particular due 

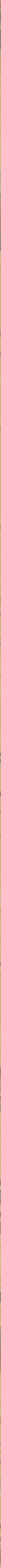
animais em filas monótonas. Pelo estilo decorativo e em particular pelos detalhes das incisões, esta olpe enquadra-se na chamada terceira geração dos pintores de Vulci, com uma fortíssima atividade produtiva (Martelli 1987: 28), e Influenciada pela segunda geração da fase média da escola de pintores de Vulci (Szilágyi 1986 e 1992; Martelli 1987: 282.69).

Publicado em: VGPortugal: 77.01.

to the details of the incisions, this olpe belongs to the so-called third generation of Vulci painters, with highly productive activity (Martelli 1987:28) and influenced by the second generation of the mid-phase of the Vulci school of painters (Szilágyi 1986 and 1992; Martelli 1987: 282.69).

Published in: VGPortugal: 77.01 


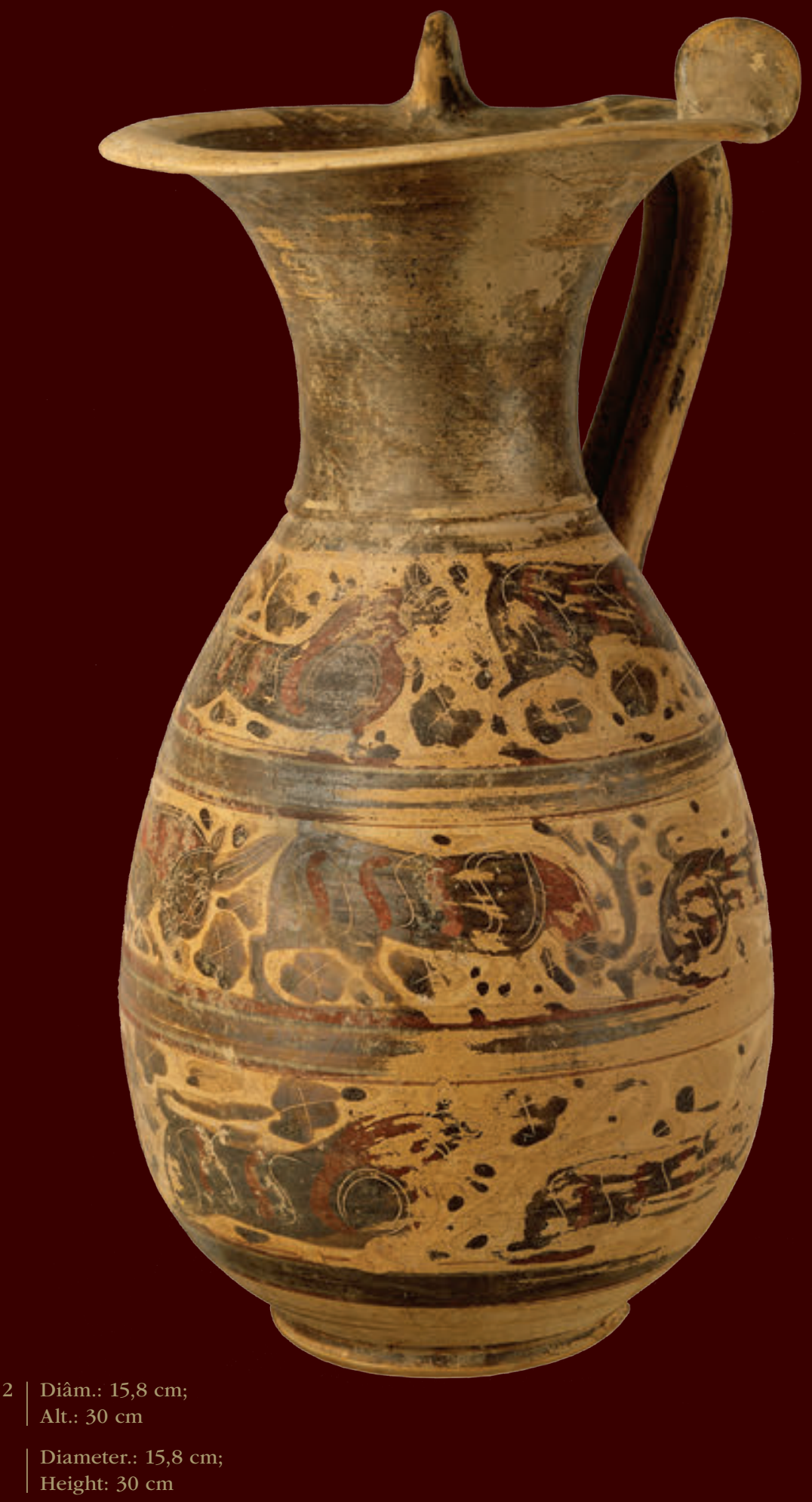


Olpe com aletas circulares • C. 580-560 a.C.

Olpe idêntico ao anterior e provavelmente oriundo da mesma oficina, apenas se diferenciando pela adição do touro e do leopardo.

Publicado em: VGPortugal: 77.02 .

Olpe with rotelles • C. 580-560 B.C.

Olpe, identical to the previous one and probably from the same workshop, whose only difference is the addition of a bull and a leopard.

Published in: VGPortugal: 77.02. 



\section{ESTILO ÁTICO DE FIGURAS NEGRAS AT'TIC BLACK-FIGURE STYLE}



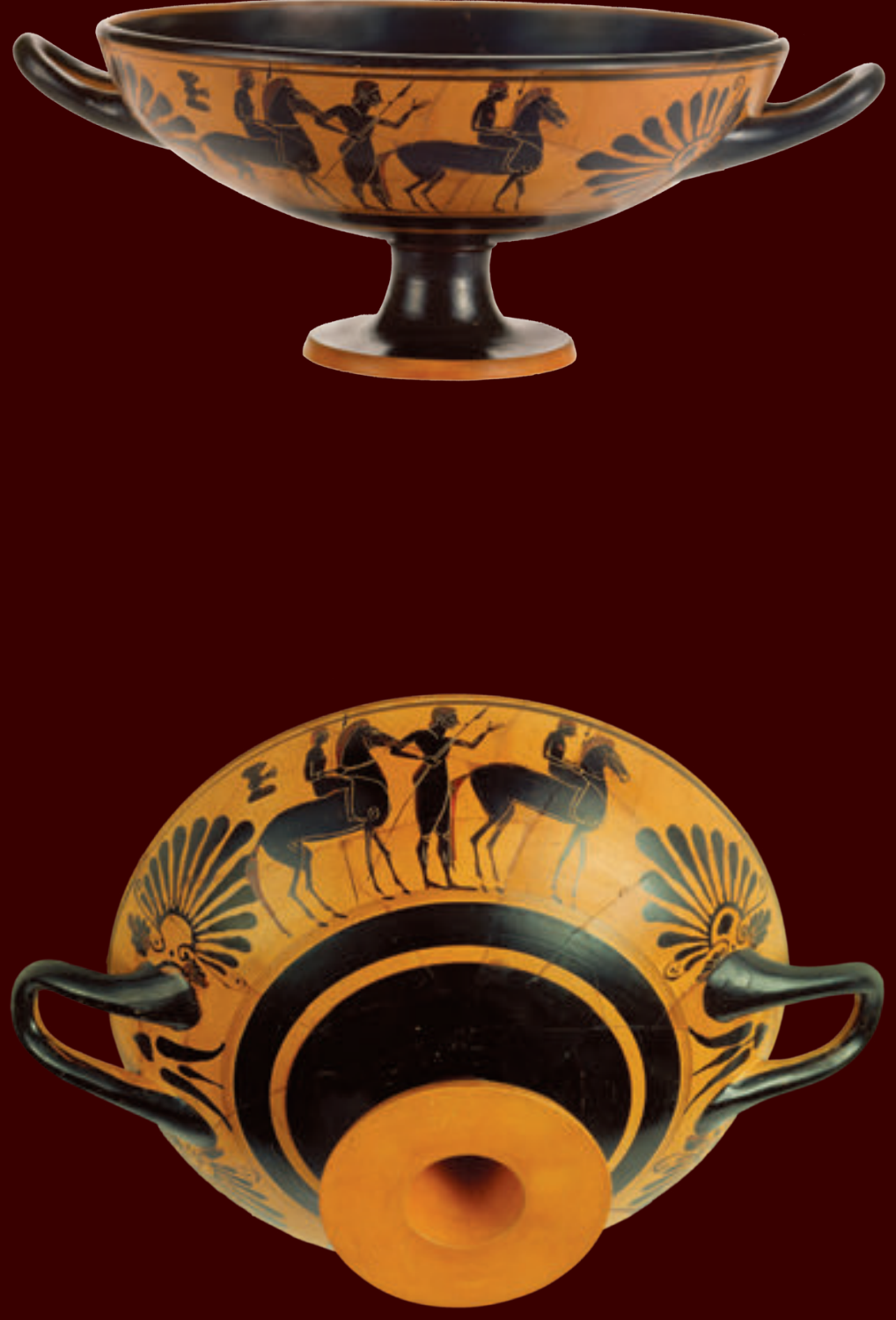

3.1 Diâm.: 29,1 cm (incluindo as asas);

3.2 Alt.: $11,1 \mathrm{~cm}$

Diameter.: 29,1 cm (including handles);

Height: $11,1 \mathrm{~cm}$ 
Taça de tipo B • Pintor de Lancastre, c. de 550-500 a.C.

Cena de equitação nos dois lados da face externa com o mestre em pé à direita, com lança na mão direita, entre dois jovens aprendizes, nus, a passo à direita, segurando rédeas na mão direita e lança na esquerda; acrescentos a vermelho nos cabelos e nas crinas e caudas dos cavalos. À esquerda na parte superior da cena, falcão voando no mesmo sentido. A ladear as asas, palmetas rematadas por duas pequenas volutas e palmetas com acrescentos a vermelho. Sob as asas, flor de lótus. Faixa reservada na transição para o pé. No interior da taça, um medalhão reservado com ponto central e círculo. Peça restaurada a partir de fragmentos e pé refeito.

No Staatliches Lindenau-Museum, em Altenburg, encontra-se uma taça do mesmo pintor ( $C V A$ Germany 17 , Taf. 40.1.4.6) com represen-

Type B Cup - Lancastre Painter, c. 550-500 B.C.

Horse-riding scene on both sides of the external surface, depicting the master standing to the right with a spear in his right hand, between two naked young apprentices to the right, holding reins in their right hand and spears in their left hand; the hair, manes and tails of the horses have touches of red. To the left, in the top half of the scene, a falcon is flying in the same direction. Flanking the wings, there are palmettes topped by two small volutes and palmettes with touches of red. Beneath the wings, a lotus flower. There is a reserved band where the transition to the foot occurs. The inside of the cup has a reserved medallion with a central, circular point. The piece has been restored from fragments and the foot re-made.

There is a cup by the same painter at the Staatliches Lindenau-Museum, in Altenburg (CVA Germany 17, Taf. 40.1.4.6) with a similar 

tação afim, três jovens cavaleiros ladeados por dois mestres de equitação, todos à direita, e falcão sobrevoando a cena à esquerda (Fotos 3a-c). Pormenores do desenho, designadamente a representação dos olhos e das mãos, bem como as linhas de incisão e os acrescentos a vermelho revelam tratar-se do mesmo artista.

Podem encontrar-se taças com conexões estilísticas e temáticas afins, normalmente atribuídas ao Pintor dos Corredores (Runners Painter), (Olmos 1993: 97-98, n. 29; CVA Germany 57, Taf. 50,4-5 e 51, 1-2), mas de inferior qualidade artística, muito provavelmente influenciadas pela obra do pintor do nosso exemplar. Tendo em conta a qualidade estilística evidenciada no vaso em estudo e no referido exemplar do Museu de Altenburg, consideramos destacar a atribuição conjunta das duas taças a um mesmo artista, propondo-se a designação de Pintor de Lancastre.

Publicado em: VGPortugal: 80.05

representation, three young horsemen flanked by two equitation masters, all placed on the right side and a falcon flying over the scene to the left (photos 3a-c). Details of the drawing, such as the representation of the eyes and hands, as well as the incision lines and the touches in red, reveal that it is indeed the same artist.

It is possible to find cups with similar stylistic and thematic connections, normally assigned to the Runners Painter, (Olmos 1993: 97-98, nr. 29; CVA Germany 57, Taf. 50,4-5 and 51, 1-2), but of inferior artistic quality, most probably influenced by the works of the painter of our piece. Taking in to account the stylistic quality evidenced by the vase studied here and the previously mentioned example from the Altenburg Museum, we contend both cups can be attributed to the same artist, proposing that he be named the Lancastre Painter.

Published in: VGPortugal: 80.05 . 

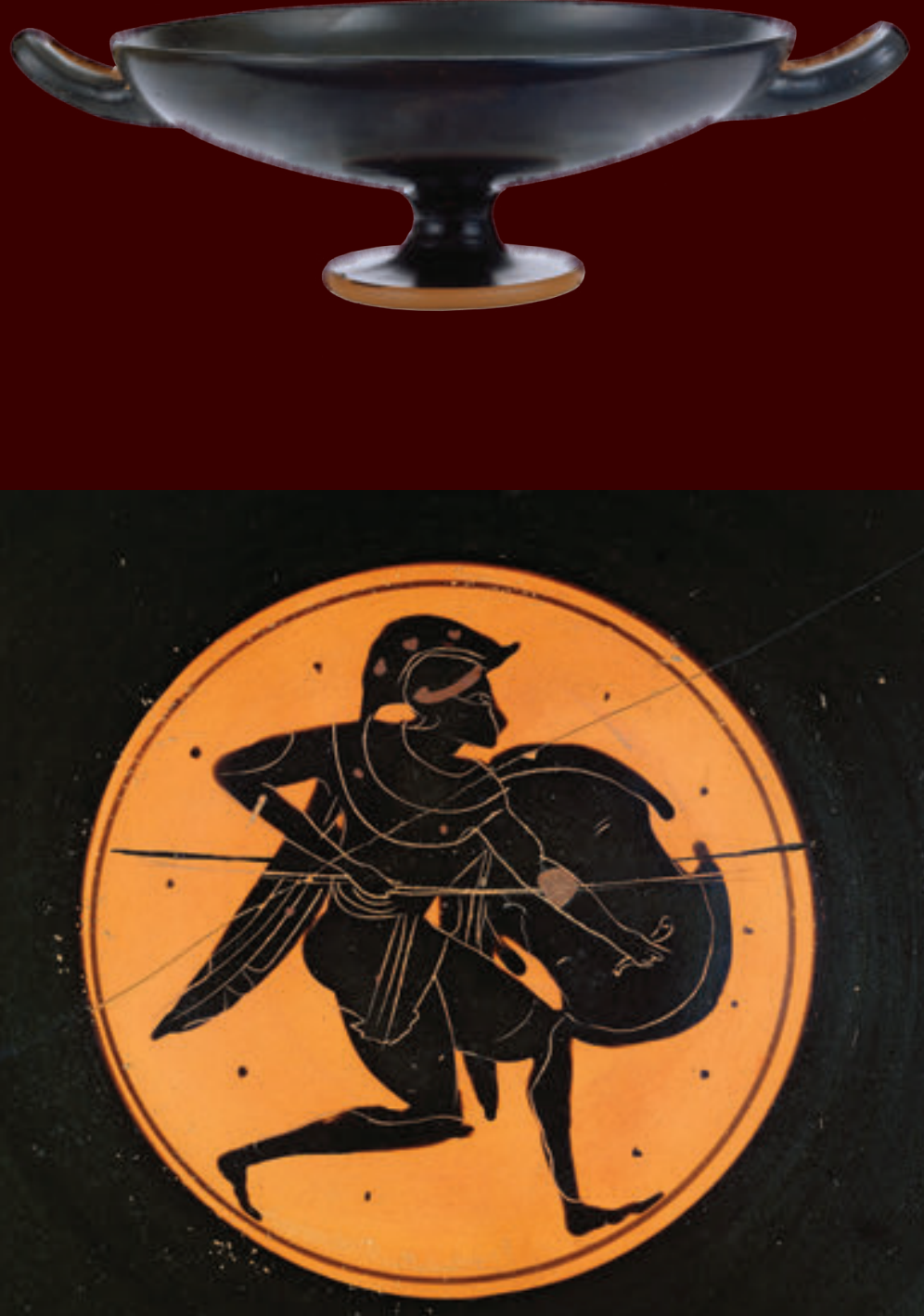

4.1 Diâm.: $30,5 \mathrm{~cm}$ (incluindo as asas);

4.2 Alt.: 9,2 cm

Diameter.: $30,5 \mathrm{~cm}$ (including handles);

Height: 9,2 cm 
Taça de tipo B • Pintor de Oltos, c. de 525-475 a.C.

Esta taça de figuras negras foi publicada como sendo provavelmente atribuível ao pintor de Oltos (VGPortugal: 81). Nesse estudo indica-se que este pintor é já sugerido no catálogo de venda da Christie's (1996), onde se refere que "o desenho é comparável com o de CVA Great Britain, Oxford, 1, III, 1, fig. 1/1, assinado por Oltos, o que parece provável" (Foto 4a). A grande maioria das obras deste pintor (cerca de 157) é de figuras vermelhas, mas também lhe são atribuídas pelo menos 24 taças tipo "eye-cup" e uma do tipo A em figuras negras (Folsom 1975: 134). Oltos é conhecido sobretudo pela pintura de taças, ainda que as suas melhores obras sejam em outras formas (Richter 1946: 49; ARV 53). Depois de uma consulta minuciosa de todos os volumes do Corpus Vasorum Antiquorum disponíveis em suporte digital e do Beazley

Cup Type B - Oltos Painter, c. 525-475 B.C.

This black-figure cup was published as probably attributable to the Oltos Painter (VGPortugal: 81). In that study, it is pointed out that this painter had already been suggested in the Christie's sales catalogue (1996), where it is said that "the drawing is comparable with that of the CVA Great Britain, Oxford, 1, III, 1, figure 1/1, signed by Oltos, which seems probable" (photo 4a). The great majority of this painter's works (about 157 pieces) are of red figures, but at least 24 eye-cup vases and a black-figure type A are attributed to him also (Folsom 1975: 134). Oltos is known for painting on cups, even though his best works are on other forms (Richter 1946: 49; $A R V$ 53).

After a thorough consultation of all the volumes of the Corpus Vasorum Antiquorum available in digital format and of the Beazley Archive, we came to the conclusion that this cup can be attributed 

Archive, constatámos que esta taça pode efetivamente atribuir-se a este pintor. Esta possui fortes afinidades com mais outras duas taças encontradas na Etrúria e atribuídas por Beazley ( $A R V 43.73$ e 55.14; 64.103 e 1600.29) àquele pintor. Uma provém de Vulci (à semelhança daquela do Museu Britânico), hoje conservada no Museu do Louvre (CVA France 17, Pl. 101, n. ${ }^{\circ}$ 1-5) (Foto 4b), e outra de Orvieto (CVA Italy 16, Tav.1-2), conservada no Museu Cívico daquela comunidade. Todos os exemplares, datados de 525-475 a.C., têm no interior um guerreiro correndo, à direita ou à esquerda, habilmente adaptado ao espaço circular, com partes da decoração reservada com acrescentos a vermelho. O guerreiro, desenhado com vigorosas linhas incisas conferindo-lhe uma aparência viril ${ }^{1}$, está representado com um elmo coríntio e segura no braço direito uma lança, que atravessa na horizontal toda a decoração, e no esquerdo um escudo beócio,

to this painter. The piece has strong similarities with two other cups found in Etruria and attributed by Beazley ( $A R V 43.73$ and 55.14; 64.103 and 1600.29) to that painter. One comes from Vulci (like the one from the British Museum), today kept at the Louvre Museum (CVA France 17, Pl. 101, nr. 1-5) (photo 4b), and the other from Orvieto (CVA Italy 16, Tav.1-2), conserved at the Civic Museum of that community. All the pieces, dated from 525-475 B.C., have a running warrior on the inside, to the left or right, skilfully adapted to the circular space, where parts of the reserved decoration have touches of red. The warrior, drawn with vigorous incision lines, giving him a virile appearance ${ }^{1}$, is represented with a Corinthian helmet and is holding in his right arm a spear, that horizontally crosses the entire decoration, and in his left arm a Boeotian shield. He is wearing a short tunic and a mantle that falls on his shoulders, and also protection greaves. 

envergando uma túnica curta e um manto que cai sob os ombros e grevas de proteção.

Nas taças do Museu do Louvre e de Orvieto vê-se a toda a volta a inscrição KALOSMEMNON. No exemplar em estudo esta inscrição apenas está simulada mas não deixa de ser curioso que os pontos correspondam ao número de letras (do lado esquerdo Kalos e do lado direito Mémnon). Seria interessante associar a representação deste guerreiro ao famoso príncipe etíope, filho de Aurora, também ele chamado Mémnon, mas não possuímos dados que possam comprovar ou infirmar tal hipótese. Este exemplar, restaurado a partir de fragmentos, apenas difere das taças referidas por não possuir o exterior decorado.

Publicado em: VGPortugal: 81.06.

${ }^{1}$ Aspeto caraterístico das figuras de Oltos (Richter 1946: 49).

On the cups from the Louvre and Orvieto, the inscription KALOSMEMNON runs all the way round. On the piece studied here, this inscription is only simulated but it is still curious that the dots correspond to the same number of letters (on the left Kalos and on the right Memnon). It would be interesting to associate the representation of this warrior to the famous Ethiopian prince, son of Aurora, also called Memnon, but we do not have evidence that could prove or invalidate this hypothesis. This example, restored from fragments, only differs from the cups mentioned because it does not have a decorated exterior.

Published in: VGPortugal: 81.06.

${ }^{1}$ Characteristic feature of the Oltos Painter's figures (Richter 1946: 49). 


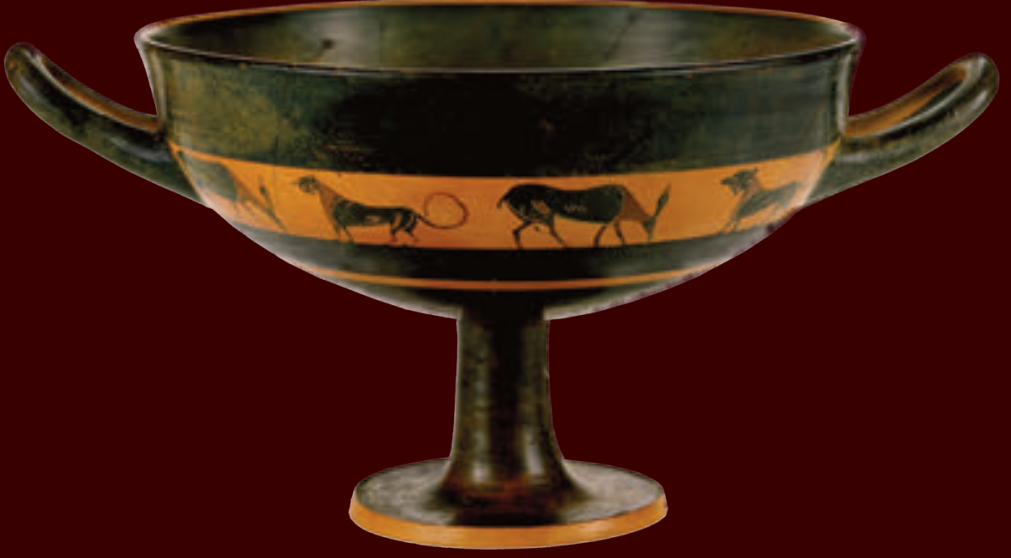

5 Diâm.: 30,5 cm (incluindo as asas); Alt.: $9,2 \mathrm{~cm}$

Diameter: $30,5 \mathrm{~cm}$ (including handles);

Height: 9,2 cm 
Taça de tipo C • Little-Master Band Cup, c. de 525-475 a.C.

Na face externa, friso a toda a volta com motivo repetido de uma cerva a pastar à direita e uma pantera à esquerda; sob a decoração, faixa reservada na transição para o pé. No interior da taça, um medalhão reservado com ponto central e círculo. Este tipo de taças é particularmente abundante, como se pode constatar na consulta do CVA e no Beazley Archive, onde se podem encontrar algumas taças com motivos similares atribuídas ao pintor de Attic Query.

Publicado em: VGPortugal: 80.04.

Type C Cup • Little-Master Band Cup, c. 525-475 B.C.

On the external surface, there is a frieze all the way round with a repeated motif, a doe grazing to the right and a panther on the left; underneath the decoration, a reserved band at the transition to the foot. This type of cups is particularly abundant, as is evident upon consultation of the CVA and the Beazley Archive, where some cups with similar motifs, attributed to the Attic Query Painter, are found. 


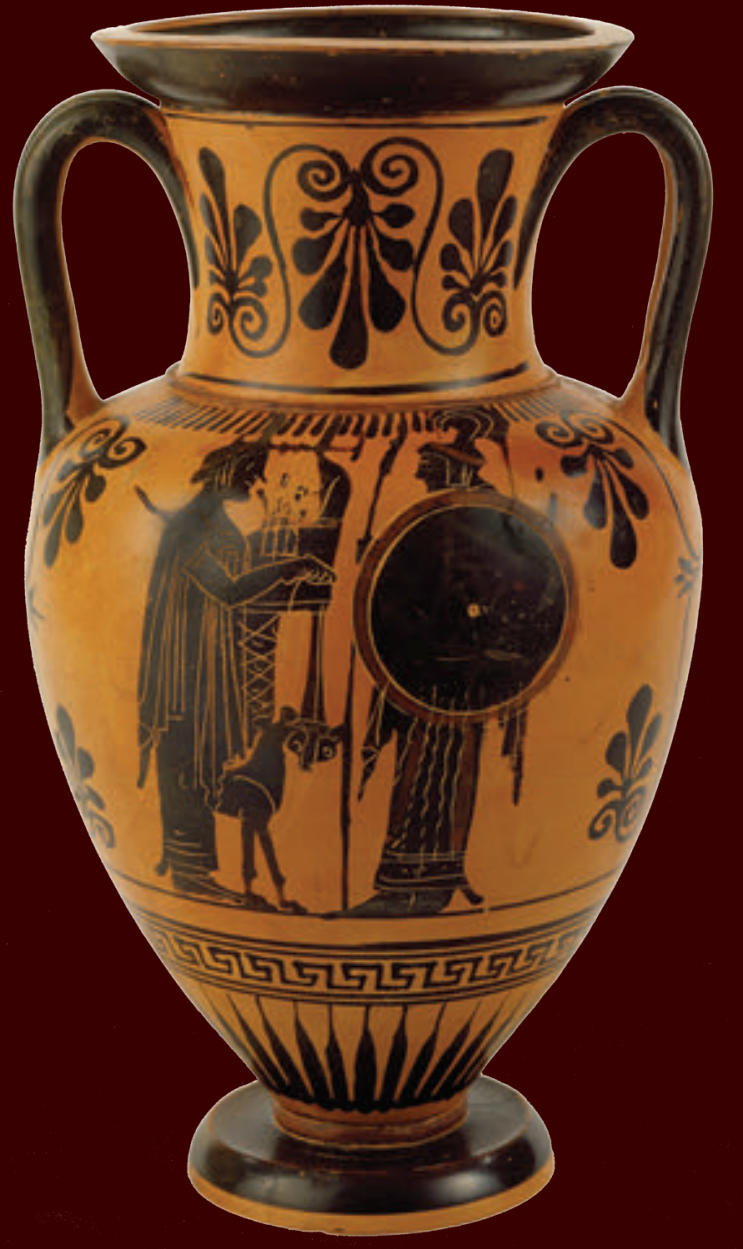

6.1 Diâm.: 14,1 cm (máx.);

Alt.: $23 \mathrm{~cm}$

Diameter.: 14,1 cm (max);

Height: $23 \mathrm{~cm}$ 
Ânfora de colo • À maneira do pintor de Antimenes, c. 530-510 a.C.

A ânfora de colo de figuras negras tem uma decoração aparentemente fácil de interpretar. No lado A estão ilustrados dois deuses com os respetivos atributos: a deusa Atena, armada de capacete e lança, em frente a Apolo, que segura uma lira e tem uma pantera por detrás. O tema do lado B representa, muito provavelmente, o célebre episódio da Ilíada (XVI, 681-683) em que Zeus encarrega Thanatos ("a Morte") e Hypnos ("o Sono") do transporte do corpo do jovem Sarpédon para o reino da Lícia, a fim de evitar a suprema maldição de morrer em terra alheia e aí poder receber as honras fúnebres. Nesta cena Thánatos e Hypnos, em trajes militares, segurando na mão esquerda lanças que se entrecruzam, não se apresentam alados. Para reforçar o aspeto dramático, o pintor representou Sarpédon, já desprovido da armadura e a ser re-

Neck-Amphora • Manner of the Antimenes Painter, c. 530-510 B.C.

The decoration on the black-figure neck-amphora is apparently easy to interpret. On the A side two gods are illustrated, with their corresponding attributes: the goddess Athena, armed with a helmet and a spear, in front of Apollo, who holds a lyre and has a panther behind him. The theme on the B side most probably represents the famous episode from the Iliad (XVI, 681-683), where Zeus charges Hypnos ("Sleep") and Thanatos ("Death") with the task of transporting young Sarpedon's body to the kingdom of Lycia, to avoid the supreme curse of dying in a foreign land and thus being able to receive funeral honours. In this scene, Thanatos and Hypnos, in military attire and holding overlying spears in their left hand, do not bear wings. To enhance the dramatic effect, the painter portrays Sarpedon with his armour removed, being carried from the battlefield by the two 


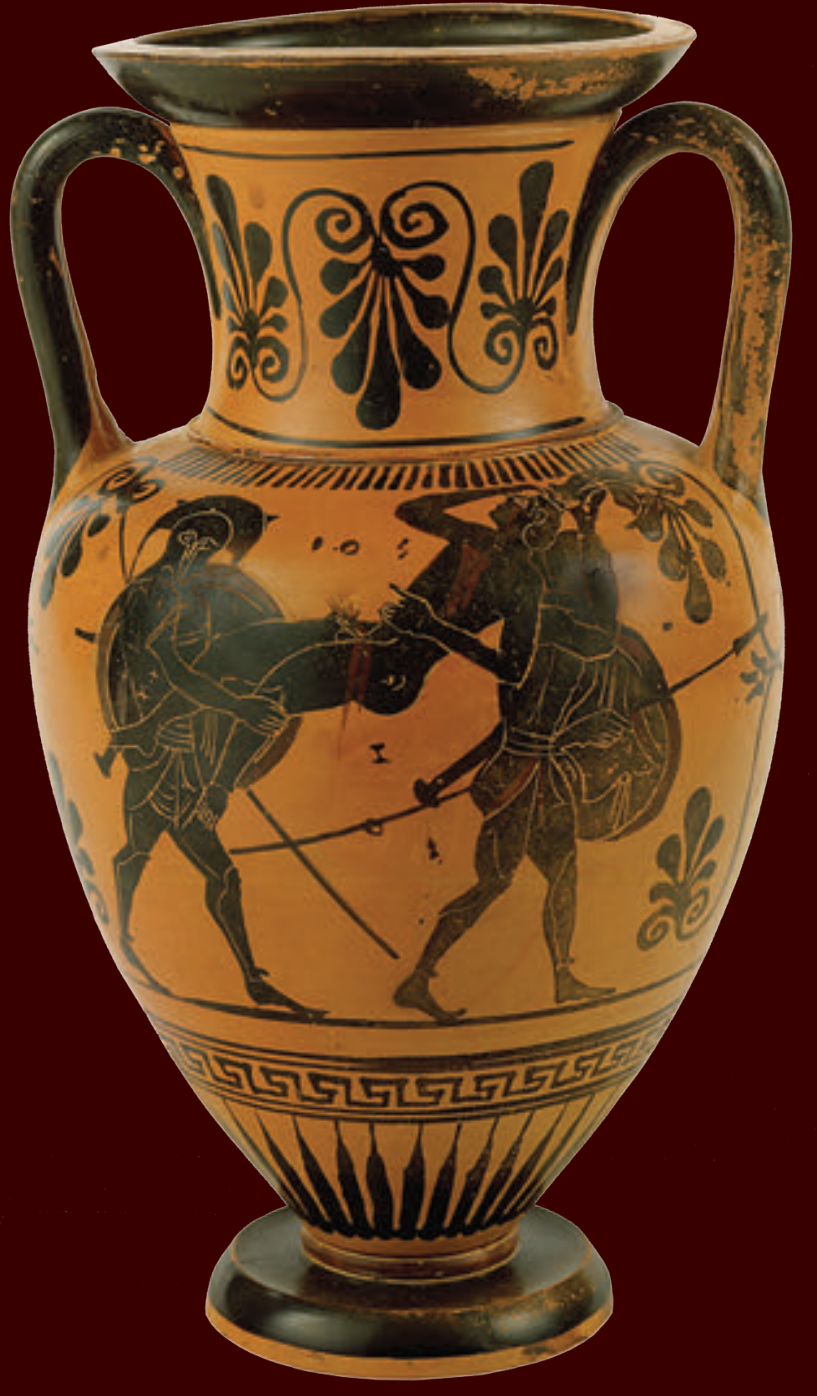


tirado do campo de batalha pelos dois génios com o braço direito acima do rosto e duas grande feridas jorrando sangue, destacadas a vermelho. No exemplar em estudo observam-se simulacros de inscrições- $\Theta(?) .0 \Sigma$ e H O — que sugerem a identificação de Thánatos à esquerda e Hypnos à direita. A representação do génio da esquerda com capacete, de frente, onde se vislumbra um olhar ameaçador, parece confirmar tratar-se de Thánatos, como já sugeriu Rocha Pereira (VGPortugal: 82).

Este é um tema presente em dez vasos áticos, aparecendo esta, seis em figuras negras e quatro em figuras vermelhas, sendo que o mais famoso até à data encontrado corresponde ao famoso calyx-kratêr pintado por Euphronios, de cerca de 520 a.C., adquirido pelo Museu Metropolitano de Nova Iorque em 1972 e atualmente no Museu Nacional Etrusco, em Roma. Segundo Efthymia Mintsi (1991: 9-20), quatro dos seis vasos de figuras negras em que a deusa Eos aparece associada a este tema, ilus-

daemons, his right arm above his face and two gaping wounds bleeding profusely, highlighted in red. The image shows simulacrums of inscriptions - $\Theta($ ?).O $\mathrm{\Sigma}$ and $\mathrm{H} \mathrm{O}$ - which may identify Thanatos to the left and Hypnos to the right. The portrayal of the daemon to the left wearing a helmet, facing forward, where we can detect a threatening glare, seems to confirm that it is indeed Thanatos, as Rocha Pereira (VGPortugal: 82) had already suggested.

This theme can be found on ten Attic vases, six of which blackfigured and four red-figured, the most famous to date being the calyx-krater painted by Euphronios, ca. 520 B.C., bought by the Metropolitan Museum of New York in 1972 and now in the National Etruscan Museum in Rome. According to Efthymia Mintsi (1991: 9-20), four of the six black-figure vases, on which the goddess Eos appears associated to this theme, illustrate the death of another hero on the Trojan side, Memnon, son of the deity. The absence of 


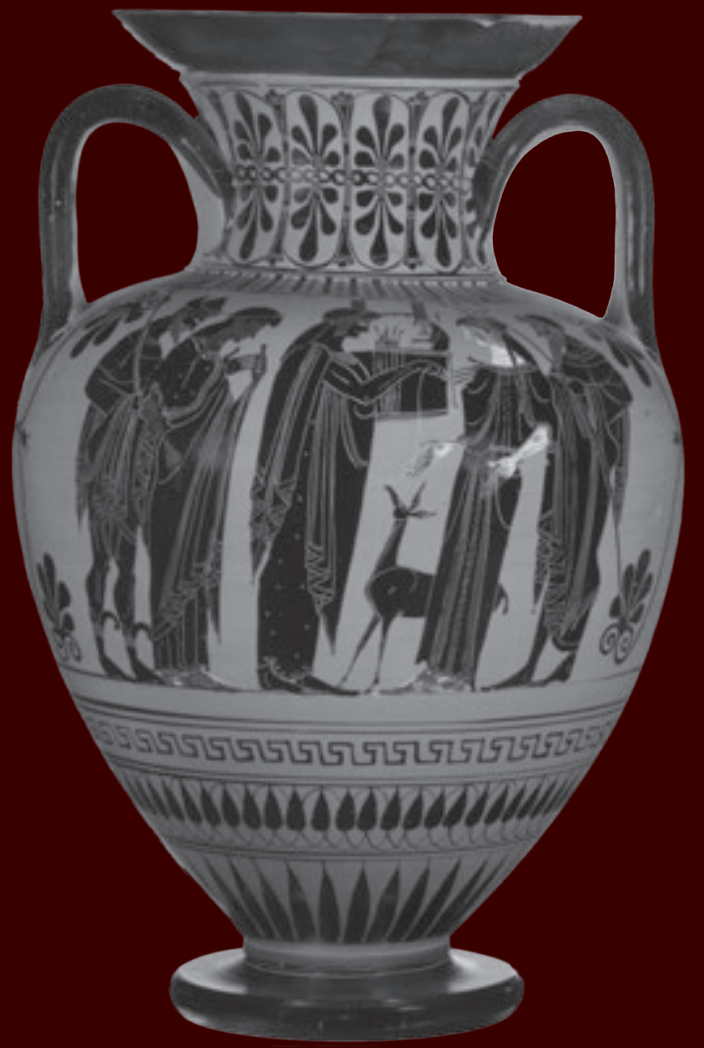


tram a morte de um outro herói do lado troiano, Mémnon, filho desta divindade. A ausência de Eos neste vaso e a presença de Apolo, no lado A, que envolveu o corpo de Sarpédon com uma mortalha (Ilíada XVI, 667-669), sugerem todavia tratar-se do tema alusivo à morte deste herói. Na consulta efectuada no Beazley Archive encontrámos uma ânfora de colo encontrada em Vulci (Etrúria), datada de 550-500 a.C., atribuída a um dos mais reputados pintores áticos de figuras negras, o pintor de Antimenes, cuja produção se situa maioritariamente entre 530-510 a.C. ( $A B F V$ 109). Nesta ânfora (CVA Germany 37, Taf. 386, n..$\left.^{\circ} 1576\right)$, conservada no Museu de Munique, estão representados a deusa Atena e Apolo, com cítara e pantera, de forma muito aproximada à representação do lado A da ânfora em estudo (Fotos 6a-b). Naturalmente que o desenho, bem como os pormenores que preenchem o resto da decoração, como no caso das palmetas representadas sob as asas e

Eos on the vase's A side and the presence of Apollo, who wrapped Sarpedon's body in a shroud (Iliad XVI, 667-669), does however suggest that the scene depicts this hero's death.

During the research we conducted at the Beazley Archive we found a neck amphora discovered in Vulci (Etruria), dated ca. 550-500 B.C., attributed to one of the most reputed black-figure painters from Attica, the Antimenes Painter, who was mostly active between 530 - 510 B.C. (ABFV 109). On this amphora, (CVA Germany 37, Taf. 386, nr. 1576), kept at the Munich Museum, Athena and Apollo are represented with zither and panther, very close to the representation on the A side of the amphora studied here (photo 6a-b). Obviously, the drawing, as well as the details that fill the rest of the decoration, as is the case of the palmettos underneath the handles and on the neck, the tabs all the way round and the radial decoration near the base, followed by meanders, as well as the poor portrayal of 


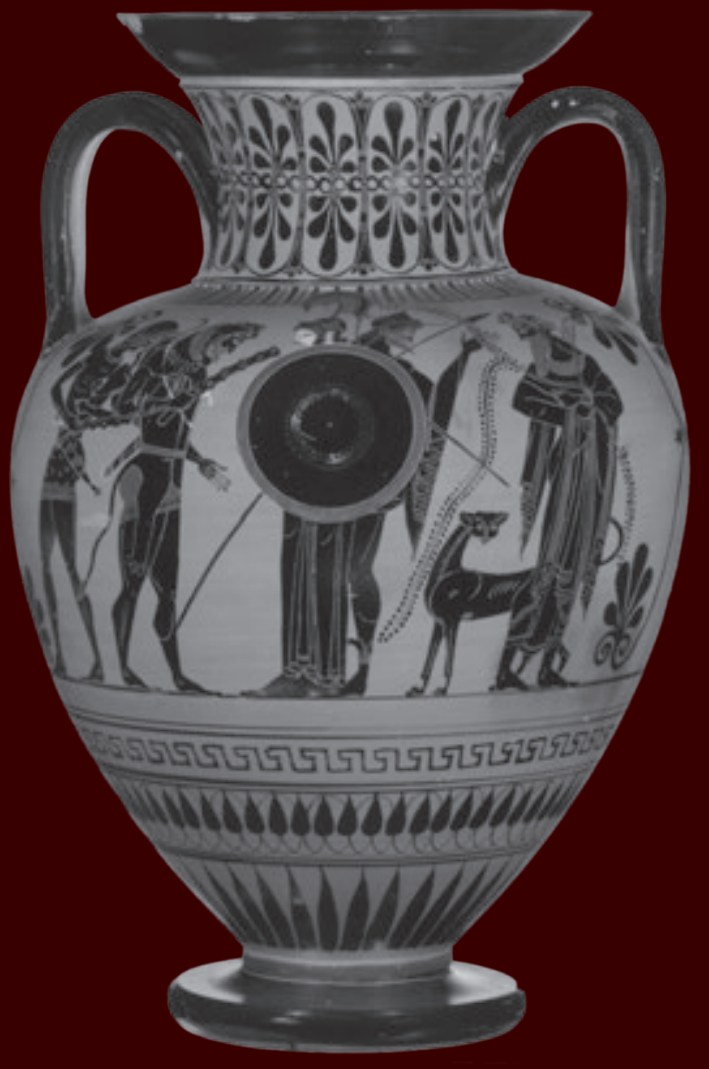


no colo e as linguetas a toda a volta e na decoração radial presente junto à base, seguida de meandros, bem como a deficiente representação da mão esquerda de Hypnos segurando a lança, não apresentam a qualidade de desenho que tanto caracteriza aquele pintor. Não vemos ainda a utilização do branco para assinalar algumas partes dos corpos das figuras, como a face e os braços, tantas vezes utilizada por Antimenes. Por estas razões, pensamos estar perante aquele conjunto de pintores que Beazley ( $A B V$ 277-9) enquadra "à maneira do pintor de Antimenes", ou seja, por ele diretamente influenciados ainda que sem a qualidade presente nas obras deste mestre.

Publicado em: VGPortugal: 82-83.07.

Hypnos' left hand holding the spear, do not exhibit the quality of this painter's drawings. We do not see yet the use of white to signal some body parts of the figures, such as face and arms, often used by Antimenes. For this reason, we believe these belong to the group of painters that Beazley ( $A B V$ 277-9) attributed to "the manner of the Antimenes Painter", in other words, directly influenced by him although without the quality of this master's works. 

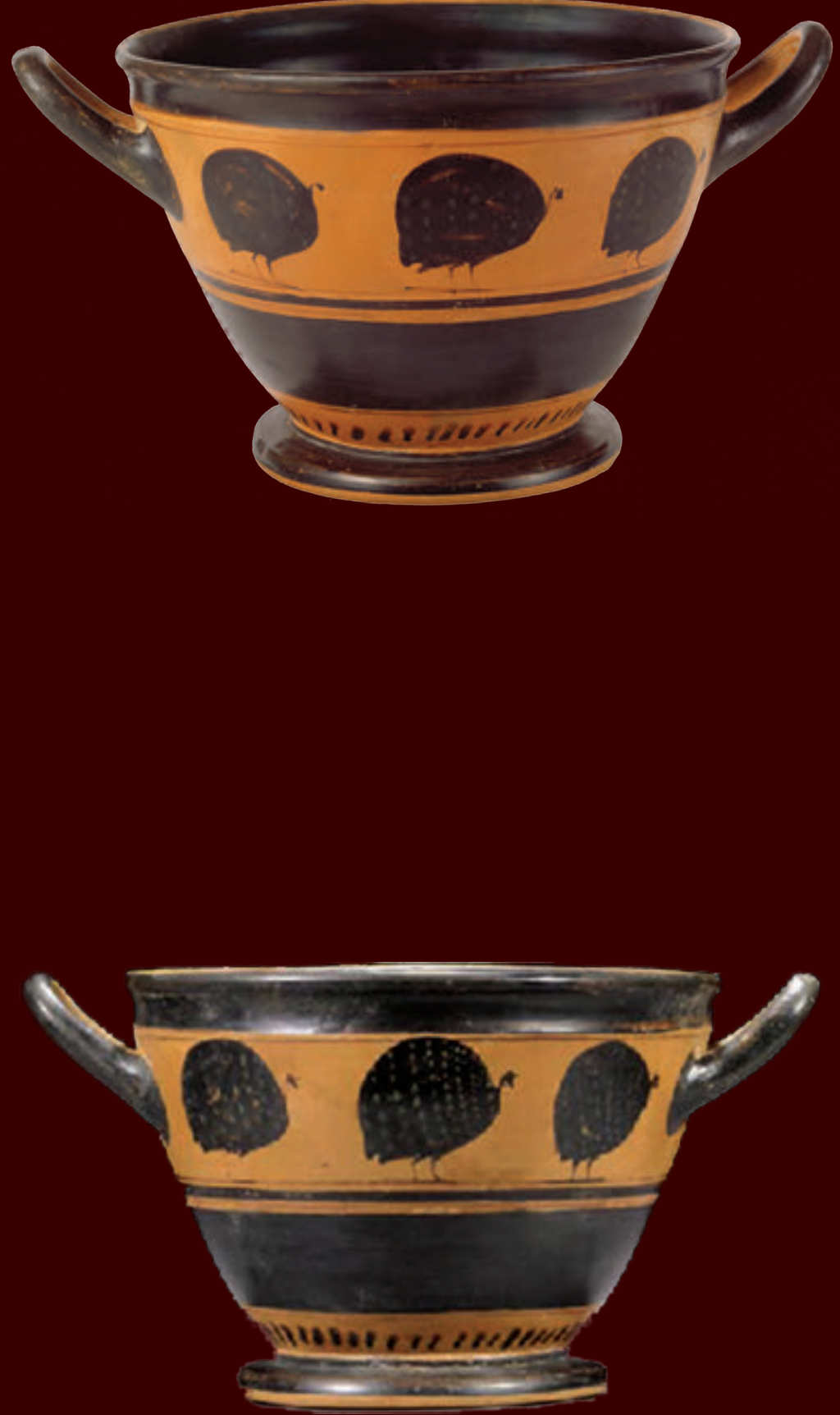

7.1 Diâm.: 22,5 cm;

7.2 Alt.: $16 \mathrm{~cm}$

Diameter.: $22,5 \mathrm{~cm}$;

Height: $16 \mathrm{~cm}$ 
Skyphos • Heron Class, c. de 525-475 a.C.

Para este skyphos, decorado com a representação de fracas e um friso de linguetas acima do pé, encontrámos um paralelo exato proveniente de Tarquínia e atualmente conservado no Museu Nacional daquela localidade (CVA Italy 26, Tav. 37, n. ${ }^{\circ}$ ). Ao vaso em estudo leiloado na Christie's (Sale 9088, London, South Kensington, 2001.04.25, Lote 161), pode-se acrescentar um outro da coleção Gallatin, hoje no Museu Metropolitano de Arte, em Nova Iorque (CVA USA 1, Pl. 8, n. ${ }^{\circ}$ 6) (Foto 7a), com uma decoração muito idêntica e seguramente do mesmo pintor; como no nosso exemplar, as fracas estão voltadas à direita e caracterizam-se por possuir um corpo volumoso, com uma penugem pintalgada, que acentua a pequenez da cabeça, do pescoço e das patas das aves. Estes três skyphoi são os únicos exemplares

Skyphos - Heron Class, c. 525-475 B.C.

Decorated with the representation of guineafowls and a frieze of tabs above the foot, this skyphos is identical to a specimen found in Tarquinia, currently kept at this city's National Museum (CVA Italy, Tav. 37. nr. 4). Apart from the vase studied, auctioned at Christie's (Sale 9088, London, South Kensington, 2001.04.25, Lot 161), another one can be added, from the Gallatin collection, presently at the Metropolitan Museum of Art, in New York (CVA USA 1, Pl. 8, nr. 6) (photo 7a), with practically identical decoration and is definitely by the same painter; like our example, the guineafowls are turned to the right and have a voluminous body, with mottled down, that accentuated the smallness of the birds' head, neck and feet. These three skyphoi are the only specimens recorded in the Beazley Archive (nrs 24155, 13823 and 13221, respectively), showing that 

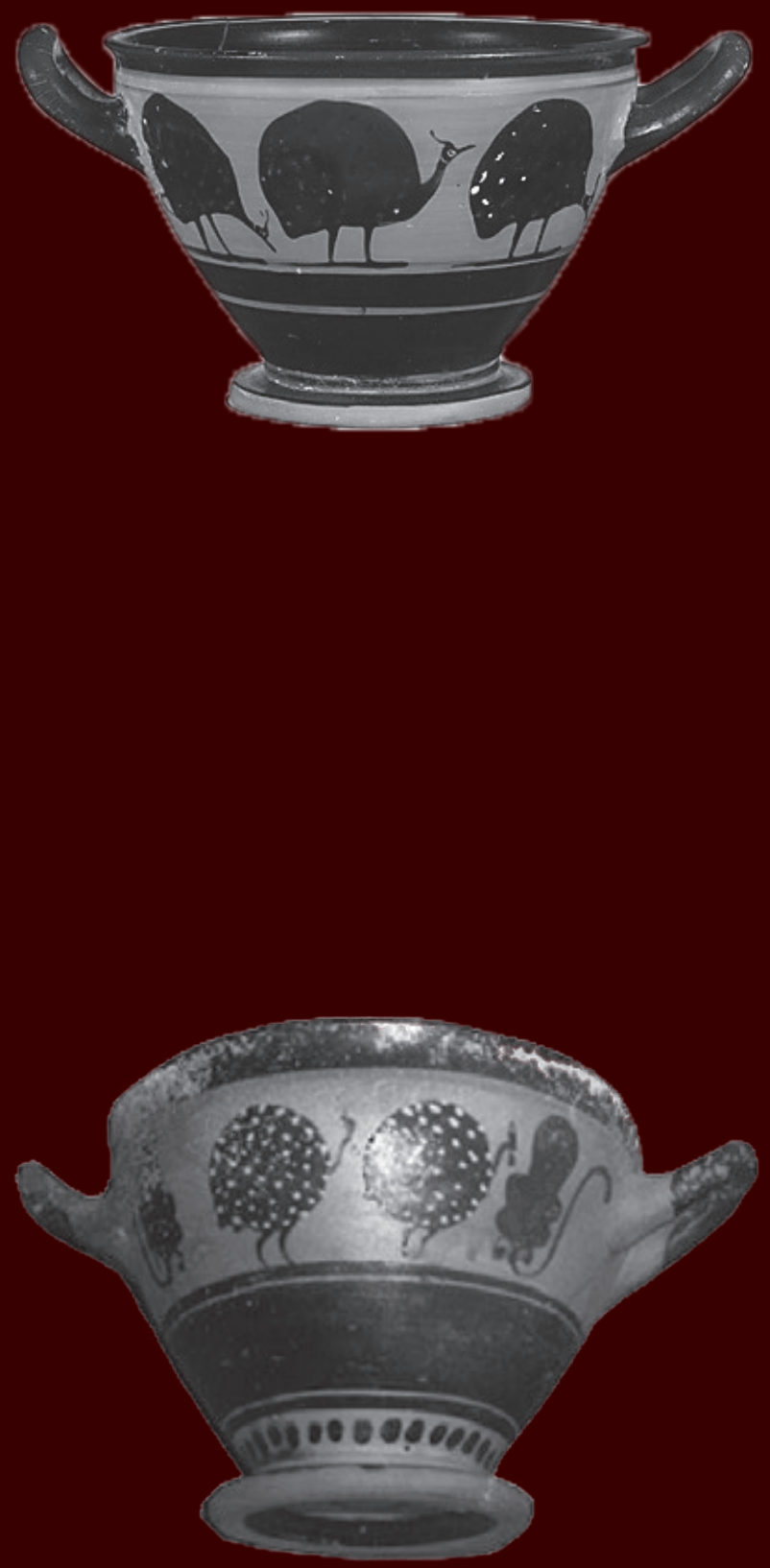
registados no Beazley Archive (n.'s 24155, 13823 e 13221, respetivamente), denotando que o motivo decorativo com a representação das fracas é pouco frequente; registam-se ainda mais dois exemplares similares, um no Museu de Palermo (Foto 7b) e outro, fragmentado, no Museu de Munique.

Todos estes skyphoi enquadram-se na Heron Class, proposta por Beazley, com temas decorativos diversos, confinados a uma banda decorativa estreita, atribuíveis a vários pintores ( $A B V 617$ e segs.).

Publicado em: VGPortugal: 88.11.

decorative motifs with guineafowl are uncommon; two other similar examples are recorded, one at the Museum of Palermo (photo 7b) and the other, fragmented, at the Munich Museum.

All these skyphoi fit in the Heron Class, proposed by Beazley, with diverse decoration themes, confined to a narrow decorative band, attributed to various painters ( $A B V 617$ and following).

Published in: VGPortugal: 88.11. 



\section{ESTILO ÁTICO DE FIGURAS VERMELHAS ATTIC RED-FIGURE STYLE}




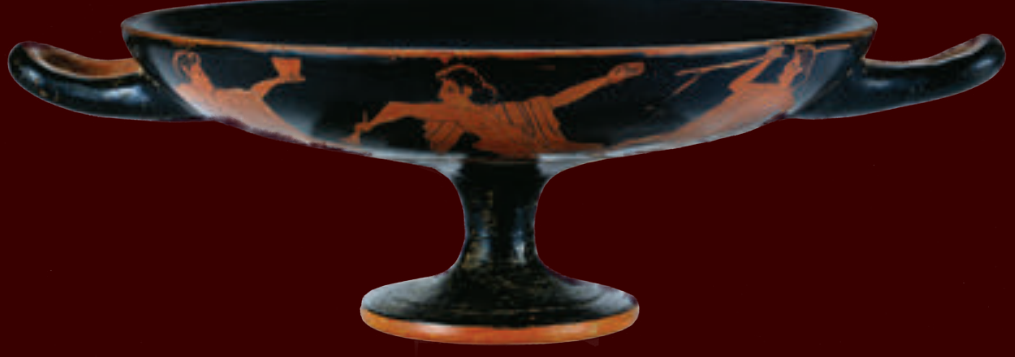

8.1 Diâm.: 32 cm;

Alt.: $8,4 \mathrm{~cm}$

Diameter: $32 \mathrm{~cm}$;

Height: $8,4 \mathrm{~cm}$ 
Taça • Grupo de Pezzino, c. 525-475 a.C.

Como nos exemplares anteriores, esta peça foi ricamente descrita no catálogo Vasos Gregos em Portugal. Aquém das Colunas de Hércules (2007: 91). O mesmo relativamente aos motivos aí representados: o interior está ilustrado com o tema da tentativa do rapto de Dejanira pelo centauro Nessos, quando a passava de uma para a outra margem do rio Eveno, na Etólia, e no exterior duas cenas semelhantes com três jovens de clâmide pelos ombros, a correr. Esta cena do rapto tem considerável expressão na iconografia, tendo sido várias vezes representada em vasos gregos (e.g. Pintor do Vaticano, Pintor de Aristófanes, Pintor de "Primato"), e noutros suportes iconográficos1, mas também presente em obras literárias, como em Sófocles (As Traquínias, vv. 555-581), Diodoro Sículo (4.36.3), Estrabão (Geografia 10.2.5), Ovídio (Heroides 9. 138-144; Metamorfoses 9.101-sqq; 12.308-

Cup • Pezzino Group, c. 525-475 B.C.

As in previous examples, this piece has been richly described in the catalogue, Vasos Gregos em Portugal. Aquém das Colunas de Hércules (2007: 91). The same applies to the motifs represented there: the interior is illustrated with the theme of the attempt of the centaur Nessus to kidnap Deianira, when ferrying her across the river Evinos, in Aetolia, from one bank to the other and, on the exterior, two similar scenes with three young people wearing a chlamys over their shoulders, who are running. This scene of the kidnapping is widely represented in iconography, having been depicted various times on Greek vases (e.g., Vatican Painter, Aristophanes Painter, Primato Painter) and on other iconographic items1, but is also present in literary works, such as Sophocles (The Trachiniae, vv. 555-581), Diodorus Siculus (4.36.3), Strabo (Geographica 10.2.5), 

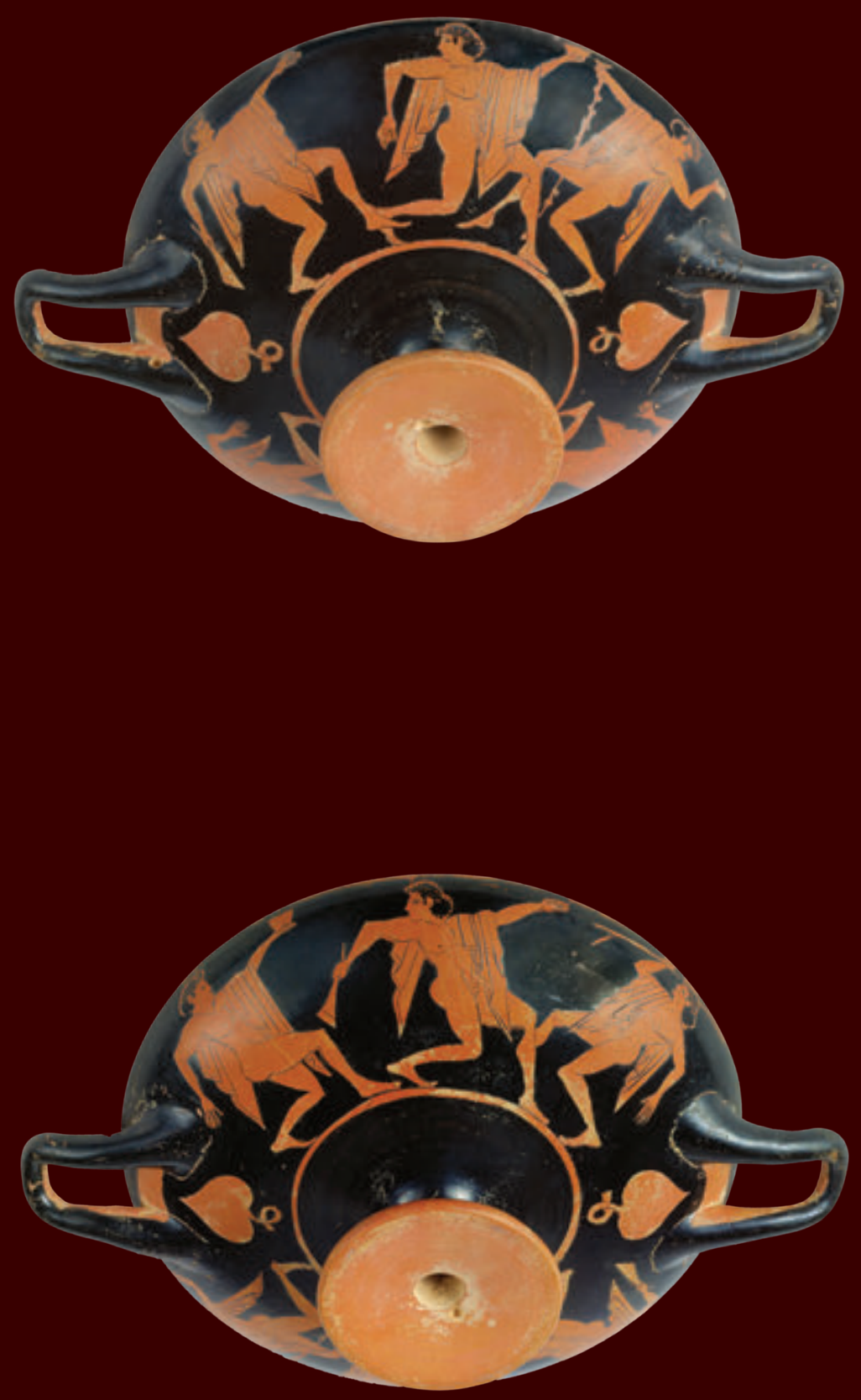
310), Apolodoro (Biblioteca 2. 151), Pausânias (10.38.1), (apud Ferreira 2008: 85-88), e Baquílides (Dit. 16), (apud Jesus 2008: 89-90).

Para a identificação deste pintor chamou-nos a atenção o motivo da folha de hera representado sob cada asa. A pesquisa efectuada no Beazley Archive permitiu constar que não se tratava de uma representação habitual, estando apenas presente (e em pequeno número) em alguns pintores, como o pintor de Epiktetos e de Tarquínia. Chamounos a atenção, no entanto, o modo como se representam os jovens e as suas clâmides que terminam de forma apontada, com linhas de pregas verticais que terminam em forma de V, um tipo de desenho característico do pintor do Grupo de Pezzino. De entre os vários vasos atribuídos a este pintor destacamos uma taça encontrada na Etrúria, atualmente conservada no Museu Arqueológico Nacional de Nápoles, e atribuída por Beazley ao Grupo de Pezzino ( $A R V$ 32.4) cujos produtos

Ovid (Heroides 9. 138-144; Metamorphoses 9.101-sqq; 12.308-310), Apollodorus (Bibliotheca 2. 151), Pausanias (10.38.1), (apud Ferreira 2008: 85-88), and Bacchylides (Dit. 16), (apud Jesus 2008: 89-90). To identify this painter, the ivy leaf motif represented under each handle caught our eye. The research done in the Beazley Archive revealed that this is not a common representation, found only (and in a reduced number) in the works of some painters, such as the Epiktetos Painter and the Tarquinia Painter. However, the way the young men are represented drew our attention, with their chlamys tapering into a point, with lines of vertical pleats that finish in a V-shape, a characteristic type of drawing by a painter of the Pezzino Group. Amongst the various vases attributed to this painter, we highlight a cup found in Etruria, at present kept in the National Archaeological Museum of Naples, and attributed by Beazley to the Pezzino Group ( $A R V$ 32.4), whose products evidence some simi- 


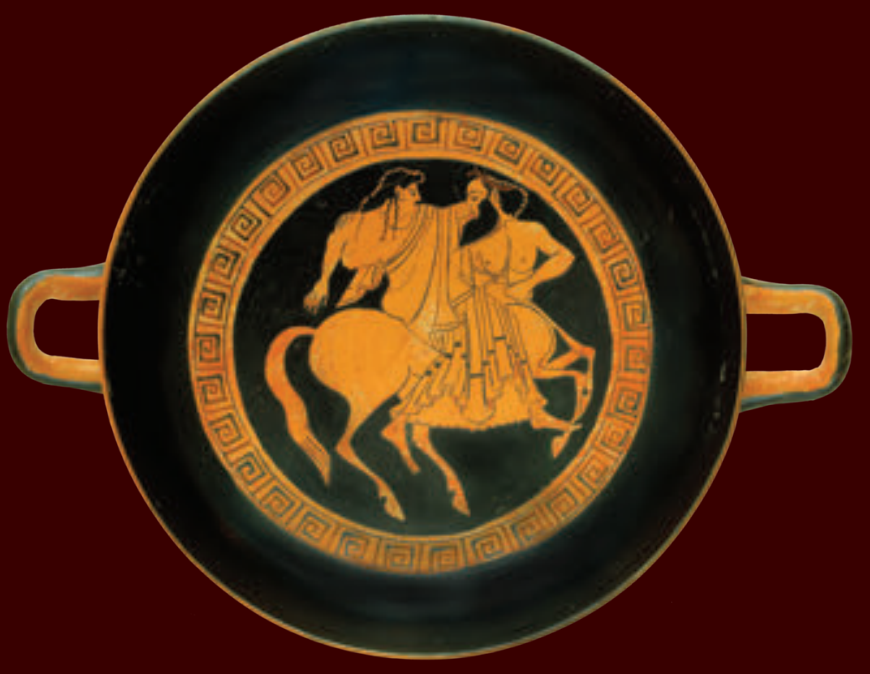

8.4 
evidenciam algumas semelhanças com os trabalhos iniciais do pintor Kleophrades ( $A R V 32$ e 114). Nesta taça, datada de cerca de 525-475 a.C., deve realçar-se, para além dos desenhos das clâmides acima referido e do motivo da hera, o mesmo modo de representar as mãos (abertas ou cerradas), os olhos e as barbas. Note-se, a propósito deste último aspeto, as semelhanças entre a representação do Diónisos na taça do Museu Nacional e do centauro Nessos da peça em estudo.

Publicado em: VGPortugal: 91.14.

${ }^{1}$ O Lexicon Iconographicum Mythologiae Classicae (LIMC) dá 125 ocorrências. A estas acrescente-se ainda uma lucerna africana tardia estudada por um dos autores (Morais 2008).

larities with the initial works of the Kleophrades Painter ( $A R V 32$ and 114). On this cup, dated from around 525-475 B.C., we should highlight that, apart from the drawing of the chlamys mentioned above and the ivy motifs, the hands (open or closed), the eyes and beards are represented in the same way. With respect to this last aspect, the similarities between the representation of Dionysus on the cup held at the National Museum and the centaur Nessus on the piece studied should be noted.

Published in: VGPortugal: 91.14.

${ }^{1}$ The Lexicon Iconographicum Mythologiae Classicae (LIMC) gives 125 examples. Another example is a late Roman African lamp published by one of the authors (Morais 2008). 

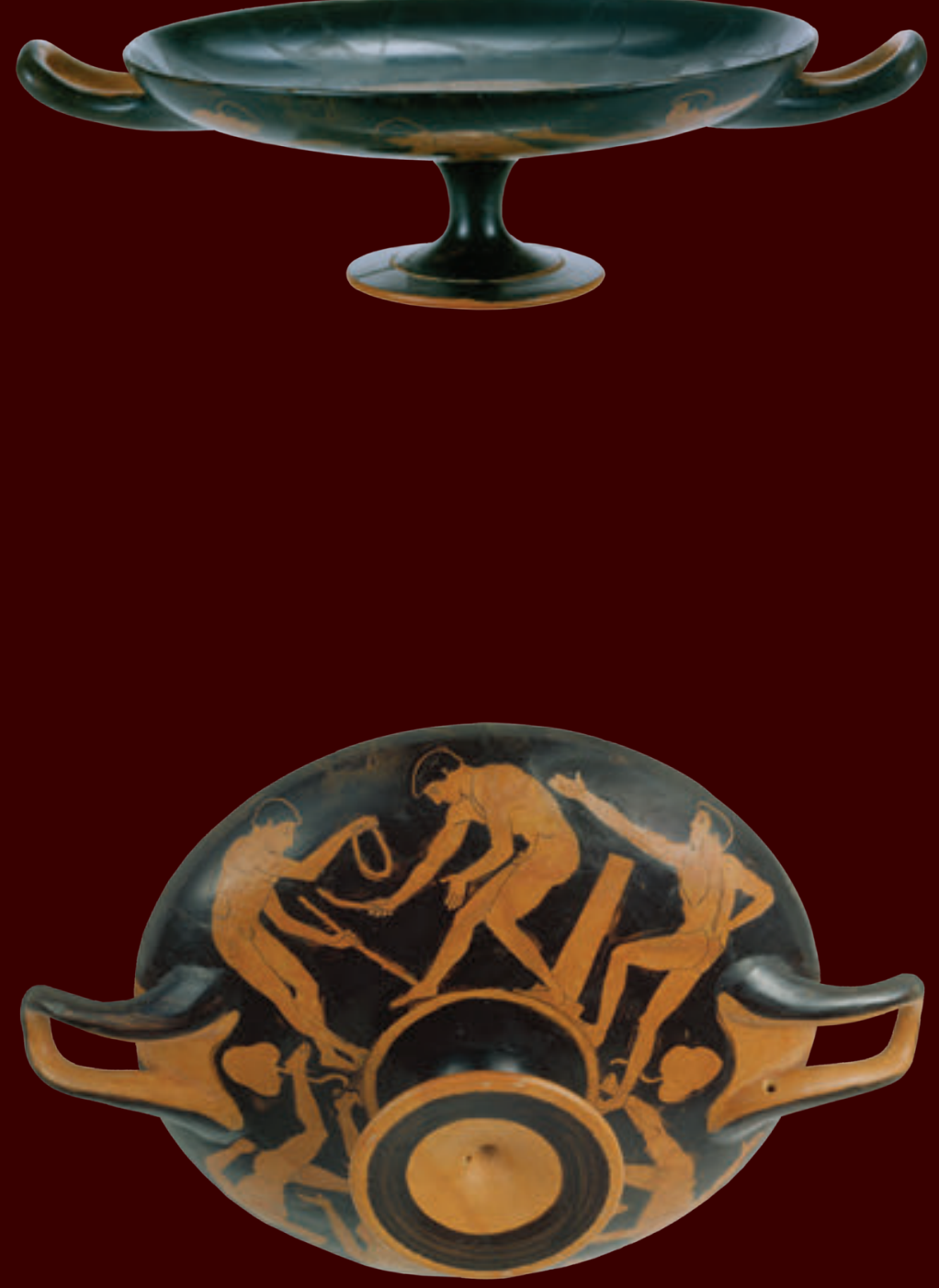

9.1 Diâm.: 23 cm;

9.2 Alt.: 7,2 cm

Diameter.: $23 \mathrm{~cm}$;

Height: 7,2 cm 
Taça • Pintor de Villa Giulia, c. de 475-425 a.C.

À semelhança da taça anterior, começámos por direcionar a nossa pesquisa centrando-nos nalguns aspetos da decoração, nomeadamente em motivos aparentemente secundários, como a representação da folha de videira sob cada asa. Recorrendo, mais uma vez e numa primeira análise, ao Beazley Archive, constatámos que este motivo não aparece com muita frequência nos vasos gregos, pelo menos em taças de figuras vermelhas.

Como se descreve no catálogo Vasos gregos em Portugal. Aquém das Colunas de Hércules (2007: 91), o motivo interior está representado com um jovem com uma clâmide sobre o ombro esquerdo. Na mão esquerda segura um bastão e na direita um rhytón que vai encher num kratêr-de-colunas, pousado no chão, à direita, deco-

Cup • Villa Giulia Painter, c. 475-425 B.C.

Like the previous cup, we based our research on some aspects of the decoration, such as the apparently secondary motifs, like the representation of the vine leaf under each handle. Using, once more and in a first analysis, the Beazley Archive, we noted that this motif is not frequent on Greek vases, at least the red-figure ones. As described in the catalogue, Vasos Gregos em Portugal. Aquém das Colunas de Hércules (2007:91), the interior motif is a young man with a chlamys over his left shoulder. He holds a bat in his left hand and a rhyton in his right hand, which he fills from a column-krater lying on the floor to the right, decorated with an ivy wreath. A crown can be seen on the opposite side. The scene is surrounded by a meandering motif. On the exterior surface of the cup, there are two scenes of a gymnasium, perceivable from 

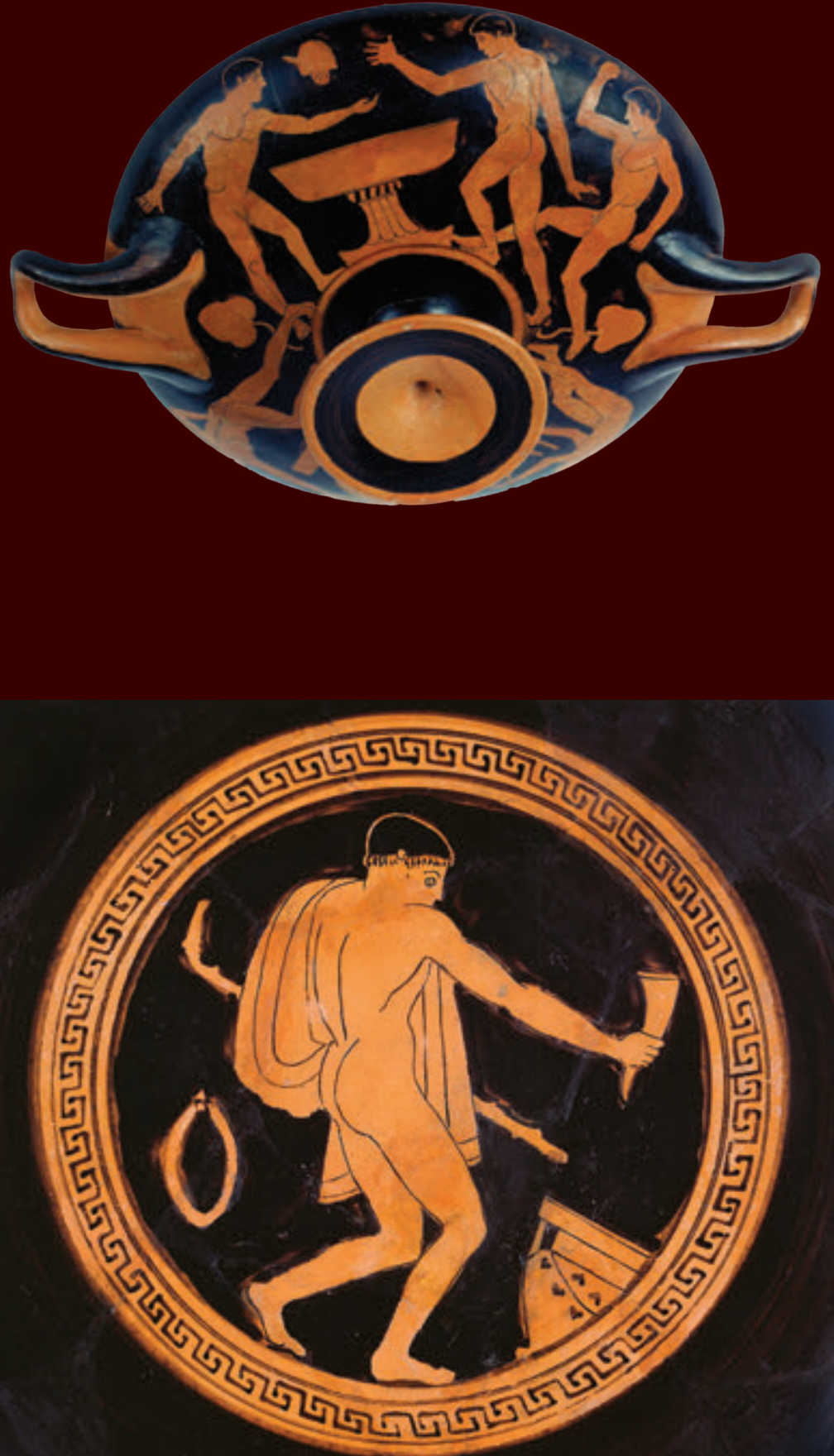
rado com uma grinalda de hera. Do lado oposto vê-se uma coroa. A cena é circundada por um motivo em meandro. No lado exterior da taça temos duas cenas de ginásio, aqui percetíveis pela representação da coluna como se assinalasse um edifício com pórticos. De cada lado temos três jovens nus, um grupo a treinar-se, outro a preparar-se para se lavar num grande labrum ao centro.

Ao analisarmos os pormenores relacionados com o modo de representação dos jovens, incluindo os movimentos e os pormenores dos cabelos, olhos e mãos, vemos fortes afinidades com o desenho característico de algumas obras do Pintor de Villa Giulia (ARV 625.101), cujo trabalhos se caraterizam, em geral, pela representação de cenas harmoniosas, mas sem grande criatividade e movimento, com figuras aparentando grande serenidade (Richter 1946: 105; Beazley, apud ARFV II 15; Folsom 1976: 130). Serve como exemplo uma taça

the representation of the column as if to signal a building with porticos. On each side, there are three naked young men, a group in training and another young man preparing to bathe in a large labrum in the middle.

While analysing the details related to the way the young men are represented, including their movements and the details of hair, eyes and hands, we see strong affinities with the characteristic drawings of some works by the Villa Giulia Painter ( $A R V$ 625.101), whose works are characterized, generally, by the representation of harmonious scenes, without much creativity and movement, with very serene figures (Richter 1946: 105; Beazley, apud ARFV II 15; Folsom 1976: 130). An example of this is a cup found in Tarquinia, now in Berlin (CVA Germany 22, Taf.130, nr 3-7), dated from 475425 B.C., depicting naked young men exercising, with anatomic traits identical to those of the cup studied here and with the same 

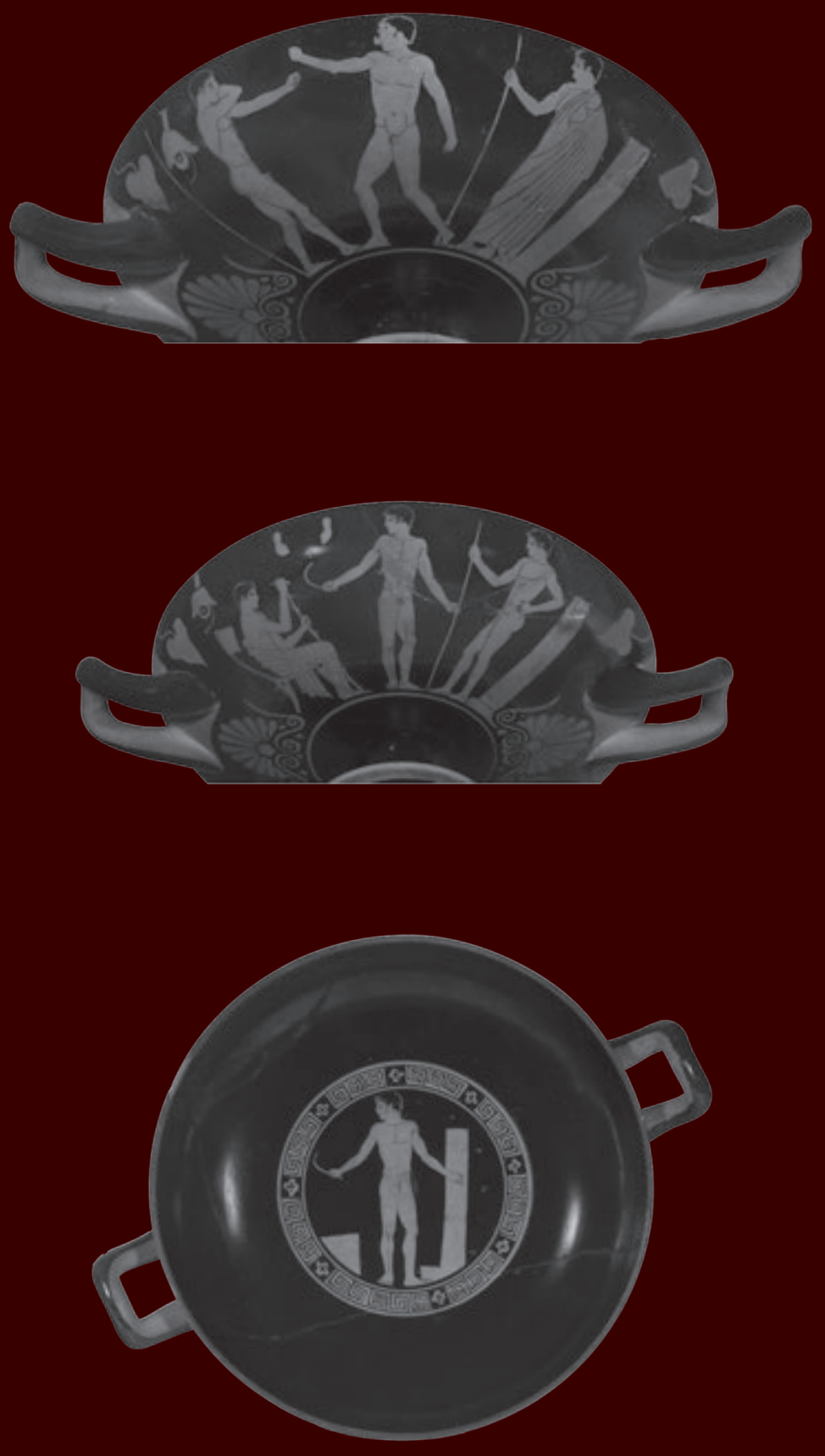
encontrada em Tarquínia, agora em Berlim (CVA Germany 22, Taf.130, n. ${ }^{\circ}$ 3-7), datada de 475-425 a.C., com a representação de jovens nus a exercitar-se, com traços anatómicos idênticos aos da taça em estudo e com o mesmo motivo da coluna (em substituição do pórtico do ginásio) e da folha de videira (Fotos 9a-c). As afinidades (nomeadamente no desenho dos olhos arredondados, dos cabelos que terminam em repas e nas mãos) são também perceptíveis no jovem representado na taça de Berlim quando comparado com o da taça agora estudada. No catálogo da Christie's (New York, Thursday 10 June 2010: 60, no 87), foi colocada em leilão uma taça de figuras vermelhas, datada de c. de 460 a.C., dada como proveniente de uma coleção privada da Suíça, que julgamos também poder ser atribuída ao Pintor de Villa Giulia.

Publicado em: VGPortugal: 91.15.

column motif (substituting the portico of the gymnasium) and vine leaf motif (photo 9a-c). The affinities (namely the drawing of the rounded eyes, hair that ends in a fringe and the hands) are also perceptible on the youth represented on the Berlin cup when compared to the cup we are studying here.

In the Christie's catalogue (New York, Thursday 10 June 2010: 60, nr 87), a red-figure cup, dated c. 460 B.C., was put up for auction, said to be from a private collection from Switzerland, that we think could also be attributed to the Villa Giulia Painter.

Published in: VGPortugal: 91.15. 


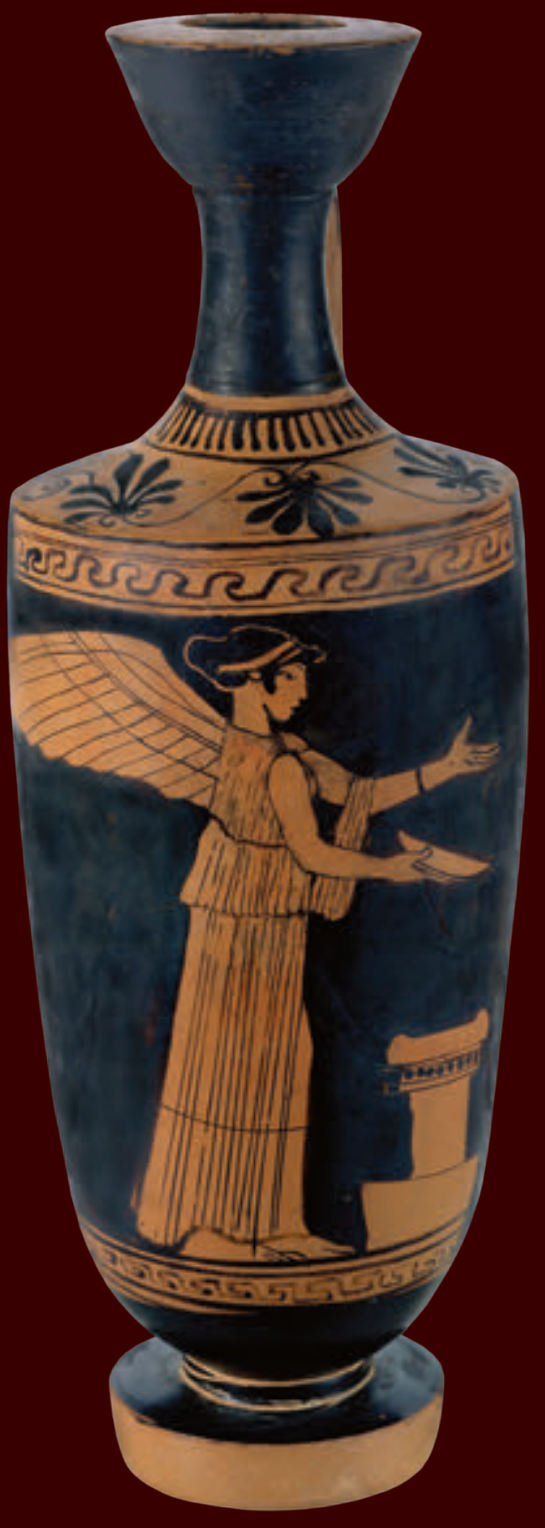

10.1 Diâm.: 8,6 cm;

Alt.: 24,2 cm

Diameter.: $8,6 \mathrm{~cm}$;

Height: 24,2 cm 
Lêkythos • Pintor de Bowdoin, c. de 475-425 a.C.

Nike, a deusa alada da Vitória, de pé à direita, com o cabelo apanhado sobre a nuca e preso com uma fita, envergando um chitón e himátion pendente no braço esquerdo, segurando uma phiale na mão direita, fazendo libações diante de um altar. Decoração de meandros simples, à direita e à esquerda respetivamente, a delimitar a parte superior e inferior da cena. Na espalda, cinco palmetas interligadas por volutas, encimadas por um friso de linguetas entre linhas horizontais. Este tipo de composição é particularmente abundante em lêkhytoi do pintor de Bowdoin e seus seguidores. São evidentes as semelhanças estilísticas e de desenho desta peça com as atribuídas à oficina daquele pintor, como se pode observar, por exemplo, nos lêkythoi

Lekythos • Bowdoin Painter, c.475-425 BC

Nike, the winged goddess of Victory, is standing to the right, her hair tied with a ribbon at the nape, wearing a chiton and himation hanging on her left arm, holding a phiale in her right hand, and making libations in front of an altar. Simple meandering decorations, to the right and left respectively, delimit the top and lower parts of the scene. On the back, there are five palmettes interconnected by volutes, topped by a frieze of tabs between horizontal lines.

This type of composition is particularly abundant on the lekhytoi of the Bowdoin Painter and his followers. The stylistic and drawing similarities of this piece and the ones attributed to the workshop of that painter are evident, as we can see, for example, on the lekythoi 


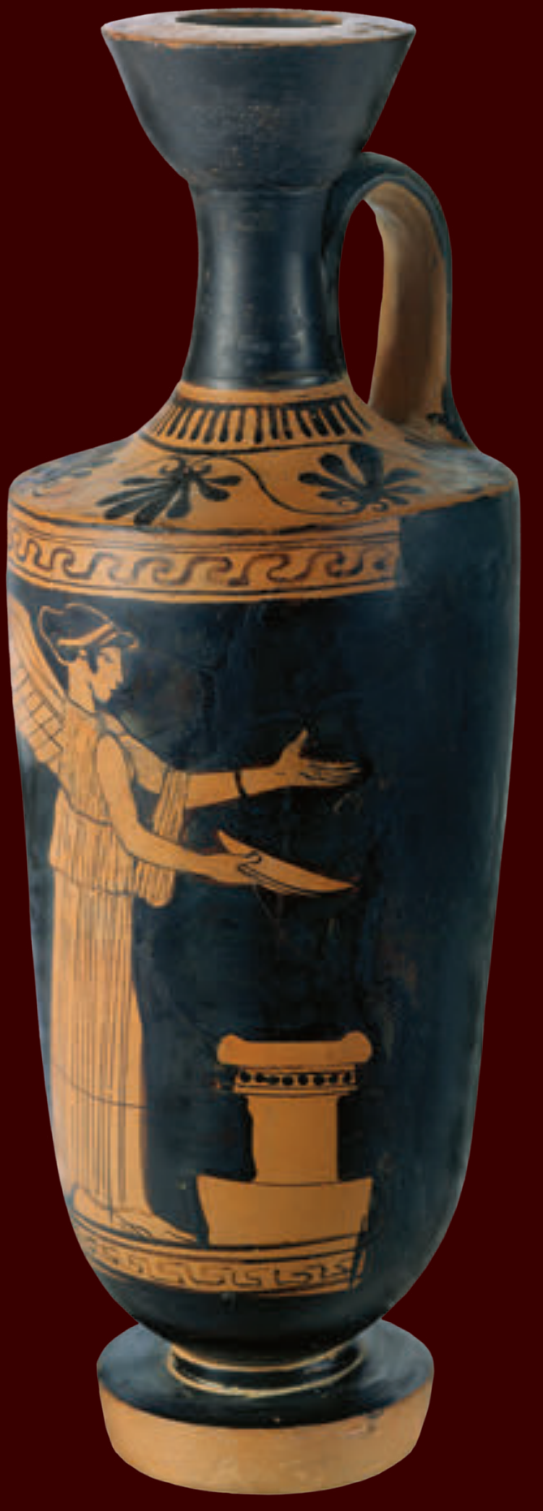

10.2 
referenciados por Beazley ( $A R V 680.79$ e 1665; Paralipomena 405 e 690.2) e na coleção do Banco da Sicília (VVAA 1992: 161, E24)

Publicado em: VGPortugal: 94.17.

referenced by Beazley (ARV 680.79 and 1665; Paralipomena 405 and 690.2) and in the Bank of Sicily collection (VVAA 1992: 161, E24)

Published in: VGPortugal: 94.17. 


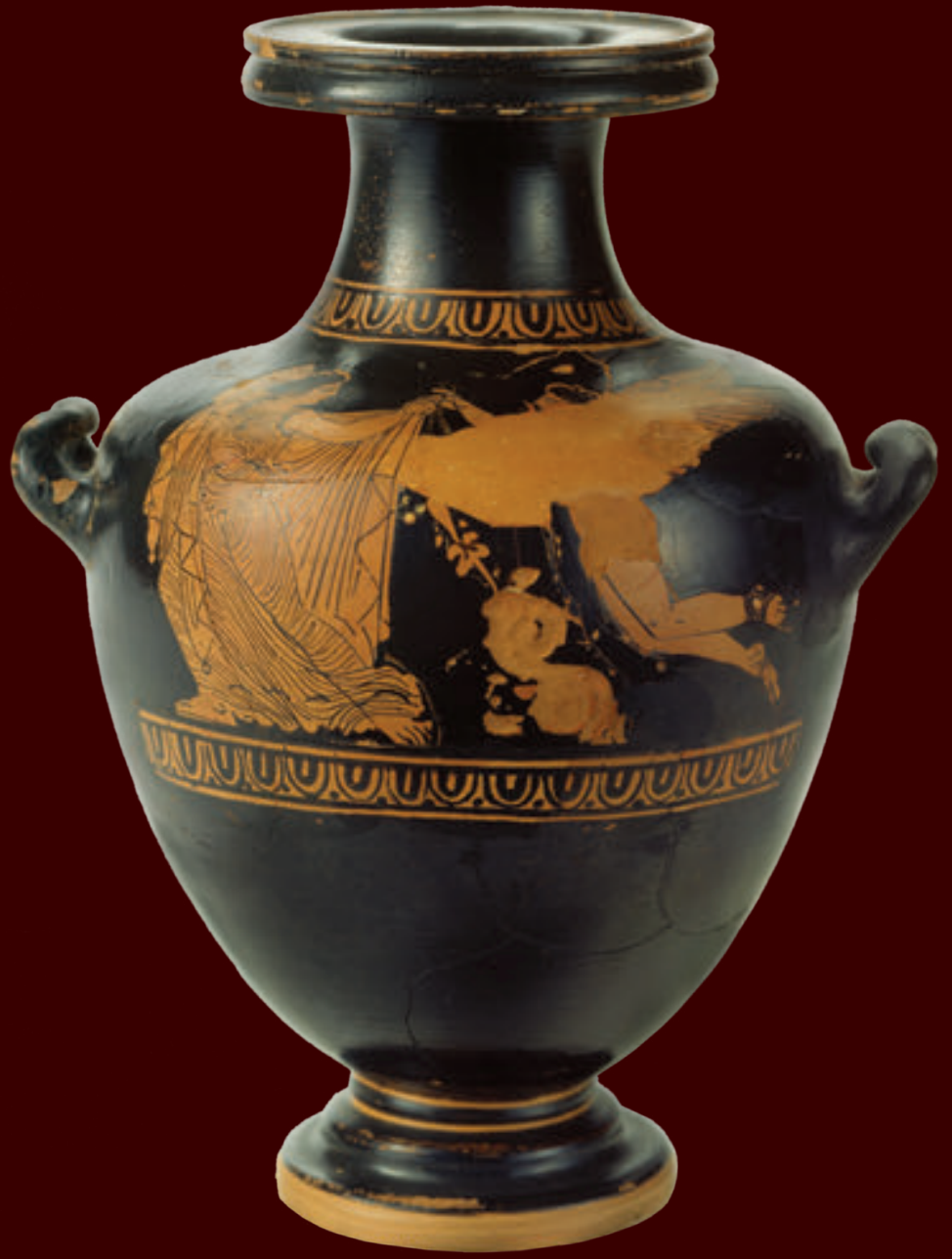

11.1 Diâm.: 7,3 cm;

Alt.: 12,3 cm

Diameter.: $7,3 \mathrm{~cm}$;

Height: 12,3 cm 
Hýdria • Oficina do Pintor de Meidias, c. de 410-400 a.C..

Motivo central com uma figura feminina à direita, representada a três quartos e cabeça de perfil, com chitôn e himátion que se desdobram em múltiplas pregas. À direita, um Eros esvoaçante, com sandálias, que tenta agarrar a mão da jovem; entre estas representações um rebento floral. A cena está superior e inferiormente limitada por um friso de óvulos e pontos. Apesar do vaso ter vindo a ser atribuído ao pintor de Aquiles (ver VGPortugal 95, n 19), o tratamento das vestes com traço impressionista, o perfil da face (nariz e olhos, em particular), o desenho das mãos e o movimento das figuras, revela tratar-se de uma obra datada do período clássico tardio (ARFV II 144-145), "com uma possível ligação [...] à produção de Meidias ou mais genericamente, à sua oficina" (Centeno 2015).

Hydria - Meidias Painter workshop, c. 410-400 B.C.

Central motif with a female figure to the right, represented at three quarters and head in profile, with chiton and himation that unfold in multiple pleats. To the right, a floating Eros, with sandals, that tries to grab the hand of the young woman; between these representations, there is a floral sprig. The scene is limited above and below by a frieze of ovules and dots. Even though the vase was attributed to the Achilles painter (see VGPortugal 95, nr 19), the treatment of the clothing, with impressionist traits, the profile of the face (nose and eyes in particular), the drawing of the hands and the movement of the figures, reveals that it is a piece from the Late Classical period, (ARFV II 144-145), "with a possible connection [to] the work of Meidias or, in more general terms, his workshop" (Centeno 2015). 

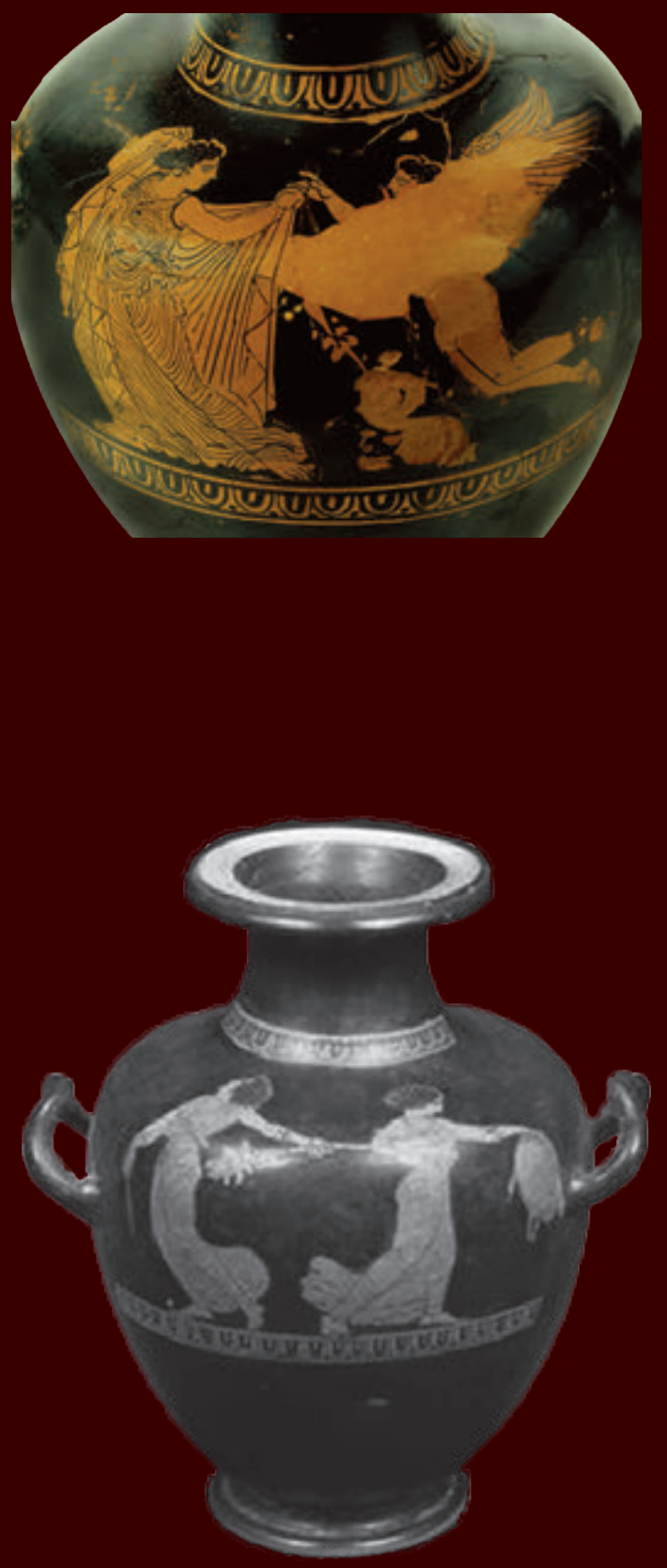
Na consulta do Beazley Archive (vaso n 45142) encontrámos uma pequena hýdria, vendida na leiloeira Bonhams em 28 de abril de 2010, atribuída à maneira de dois pintores, o de Eretria e o de Meidias (Foto 11a). "Este vaso [...] tem algumas afinidades com o nosso kálpis, nos frisos de óvulos e pontos que enquadram a cena, bem como no traço utilizado para pintar as figuras. Contudo, parece-nos que a pose das duas ménades e o tratamento das respetivas cabeleiras e faces se aproxima de duas dançarinas representadas na parte frontal do painel inferior da hýdria 259 do Badishes Landesmuseum de Karlsruhe (Burn 1987: C1 e Pl. 39), atribuída ao pintor de Karlsruhe Paris, muito próximo de Meidias mas que, para alguns estudiosos será o próprio mestre". (Centeno 2015)

Publicado em: VGPortugal: 95.19.

On consulting the Beazley Archive (vase nr. 45142), we found a small hydria, sold at the Bonhams auction on the 28th April 2010, attributed to the manner of two painters, one from Eretrei and the other from Meidias (photo 11a). "This vase [...] shows some affinities with our kalpis in the friezes of ovules and dots that frame the scene, as well as in the strokes used to paint the figures. However we believe that the pose of the two maenads and the manner in which their hair and faces are drawn is very similar to two dancers represented on the frontal part of the Power panel of the hydria 259 at the Badishes Landesmuseum in Karlsruhe (Burn 1987: C1 and Pl. 39), attributed to the Karlsruhe Paris painter, very similar to Meidias but who, for many scholars, is by the Master himself." (Centeno 2015)

Published in: VGPortugal: 95.19. 



\section{ESTILO APÚLIO DE FIGURAS VERMELHAS APULIAN RED-FIGURE STYLE}




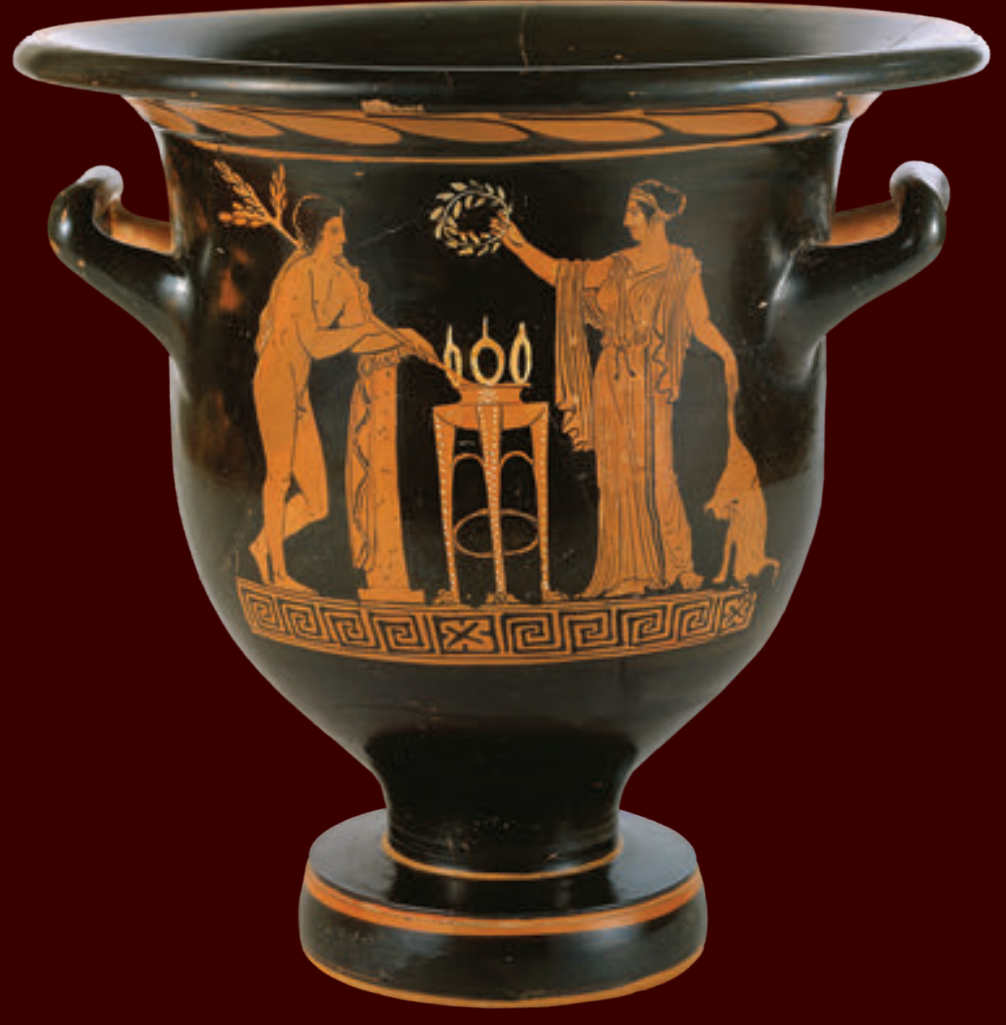

12.1 Diâm.: 35 cm;

Alt.: $32,3 \mathrm{~cm}$

Diameter.: $35 \mathrm{~cm}$;

Height: $32,3 \mathrm{~cm}$ 
Kratêr-de-sino • Pintor de Dijon, c. de 380-360 a.C.

O kratêr-de-sino atribuído ao Pintor de Dijon, graças a um paralelo conservado no Museu do Vaticano (RVAP I 148, no 6/95; RVSIS no 127128), em particular no estilo e desenho da representação da figura feminina no anverso e das figuras masculinas no reverso. Segundo a descrição do catálogo Vasos Gregos em Portugal. Aquém das colunas de Hércules (2007: 97), a cena do lado principal do kratêr representa o deus Apolo com manto pendente sobre o ombro, que se apoia numa coluna e segura um ramo de loureiro, em frente de uma figura feminina vestida com chitôn e himátion (uma sacerdotisa?); entre ambos, uma trípode, ricamente adornada. Do lado oposto, dois jovens envoltos em himátia, afrontados, um deles segurando um estrígil na mão direita o outro apoiado num bastão. De salientar o uso de branco nas

Bell-Krater • Dijon Painter, c. 380-360 B.C.

The bell-krater attributed to the Dijon Painter, thanks to a similar piece held at the Vatican Museum (RVAP I 148, nr 6/95; RVSIS nr 127-128), in particular regarding the style and drawing of the representation of the female figure on the obverse and of the male figures on the reverse. According to the description in the catalogue, Vasos Gregos em Portugal. Aquém das Colunas de Hércules (2007:97), the scene on the main side of the krater represents the God Apollo with a cloak hanging over his shoulder, leaning on a column and holding a laurel branch, in front of a female figure dressed with a chiton and himation (a priestess?); there is a richly adorned tripod between them. On the opposite side, two young men wrapped in himatia are facing each other, one holding a strigil in his right hand and the other leaning on a staff. Particularly noteworthy is the use 


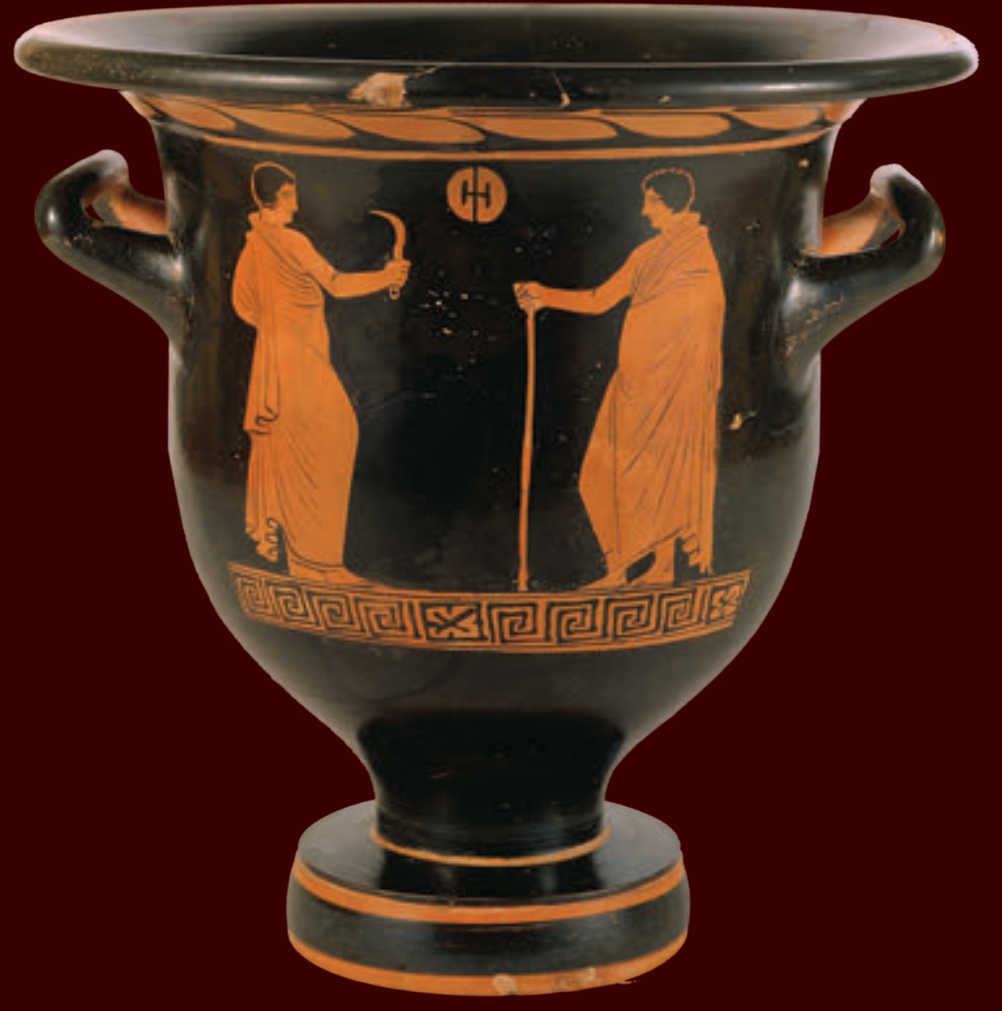


folhas, nas pregas dos mantos, no diadema da figura feminina, na pele do animal e, em particular, na trípode. Por debaixo da cena, em ambas as faces, decoração de meandros e cruzes de St ${ }^{\circ}$ André; sob o rebordo a típica representação de uma fiada de folhas de louro.

Um dos mais importantes pintores da chamada fase "Plain" style do $2^{\circ}$ quartel do século IV a.C., com fortes afinidades com os Kratêres de coluna dos Pintores de Atenas 1714 e Copenhaga 335. Pelo estilo e pelo desenho das figuras, os primeiros trabalhos do Pintor de Dijon, segundo A. D. Trendall (RVSIS 77), são muito próximos do Pintor de Karlsruhe B9 (especialmente o drapeado das vestes e as posições das figuras femininas e dos jovens representados no reverso). O vaso em estudo apresenta algumas semelhanças com um Kratêr-de-sino do Museu do Vaticano (inv. 17946) que segundo RVAp I (147-148; Pl. 46,

of white on the leaves, the folds of the cloak, the female figure's diadem, the animal's fur and, especially, on the tripod. Under the scene, meanders and St. Andrew crosses decorate both faces, and beneath the rim, a typical representation of a layer of laurel leaves. One of the most important painters from the so-called "Plain" phase style of the second quarter of the fourth century B.C., with strong affinities with the column-kraters from the Painters of Athens 1714 and Copenhagen 335. Based on style and the drawing of the figures, the first works of the Dijon Painter, according to A. D. Trendall (RVSIS 77) are very similar to those of the Karlsruhe B9 Painter (especially the draping of the clothes and the positions of the female figures and the young men represented on the reverse). The vase studied shows some similarities with the bell-krater from the Vatican Museum (inv. 17946) that, according to RVAp I (147-148; 


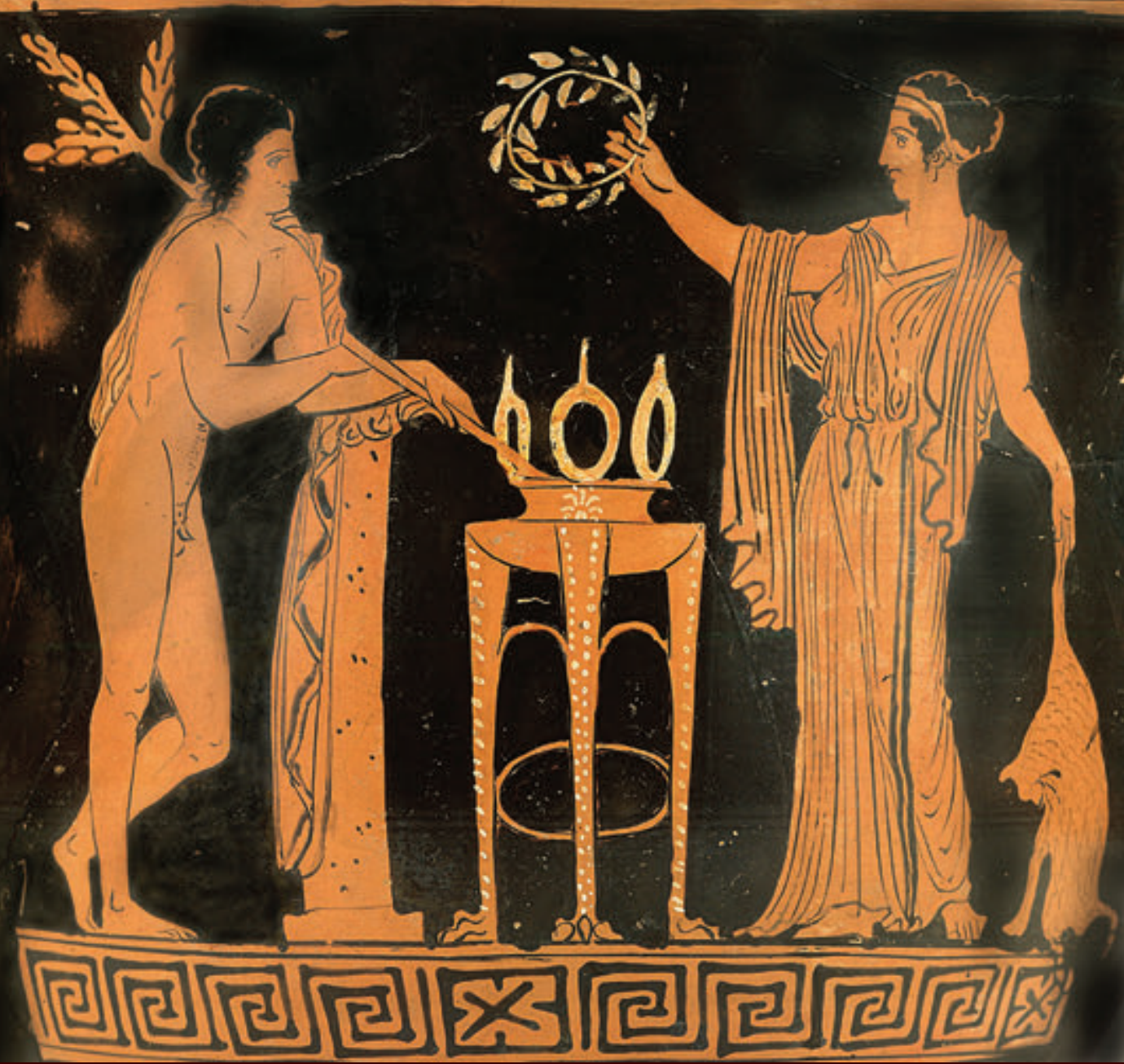


$\mathrm{n}^{\circ}$ 95) parece influenciado pelos pintores de Tarpoley e Long Overfalls (ver também RVSIS n 127-128).

Publicado em: VGPortugal: 97.21.

Pl. 46, nr 95), seems to be influenced by the Tarpoley and Long Overfalls Painters (see also RVSIS nr 127-128).

Published in: VGPortugal: 97.21. 

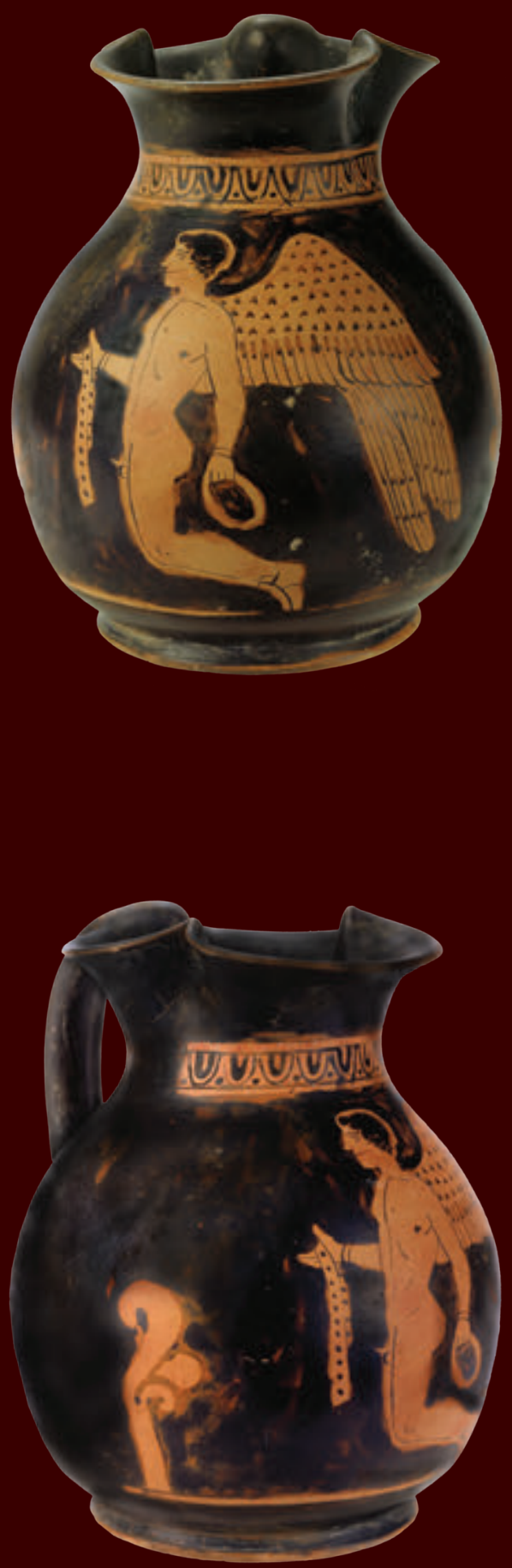

13.1 Diâm.: 10,6 cm;

13.2 Alt.: $13,3 \mathrm{~cm}$

Diameter.: $10,6 \mathrm{~cm}$;

Height: 13,3 cm 
Chous • Pintor de Reckoning, c. 380-360 a.C.

Eros esvoaçante à esquerda de pernas fletidas, desnudo e com braceletes e botins, segurando na mão direita uma fita com pontos e na esquerda uma grinalda. A delimitar a composição uma faixa de óvalos e pontos, na parte superior, e uma linha contínua na inferior; motivo floral estilizado à esquerda do Eros.

De acordo com o desenho das asas, do perfil do rosto, das mãos e das linhas que representam uma espécie de botins, este vaso pode ser atribuído ao de Reckoning. As caraterísticas assinaladas encontram um paralelo num kratêr-de-sino de Museu de Bari (RVAp I 70, n. ${ }^{\circ} 43$, Pl. 23,5$)$.

Publicado em: VGPortugal: 98.22.

Chous • Reckoning Painter, c. 380-360 B.C.

The vase depicts a floating Eros to the left, with bent legs, naked and wearing bracelets and ankle boots, holding a dotted ribbon in his right hand and a wreath in his left. A band of ovals and dots, in the top half and a continuous line in the bottom half, delimits the composition; and there is a stylized floral motif to the left of Eros. Due to the drawing of the wings, the profile of the face, the hands and the lines that represent a kind of ankle boot, this vase can be attributed to the Reckoning Painter. These characteristics are similar to a bell-krater held at the Bari Museum (RVAp I 70, nr 43, Pl. 23, 5). 

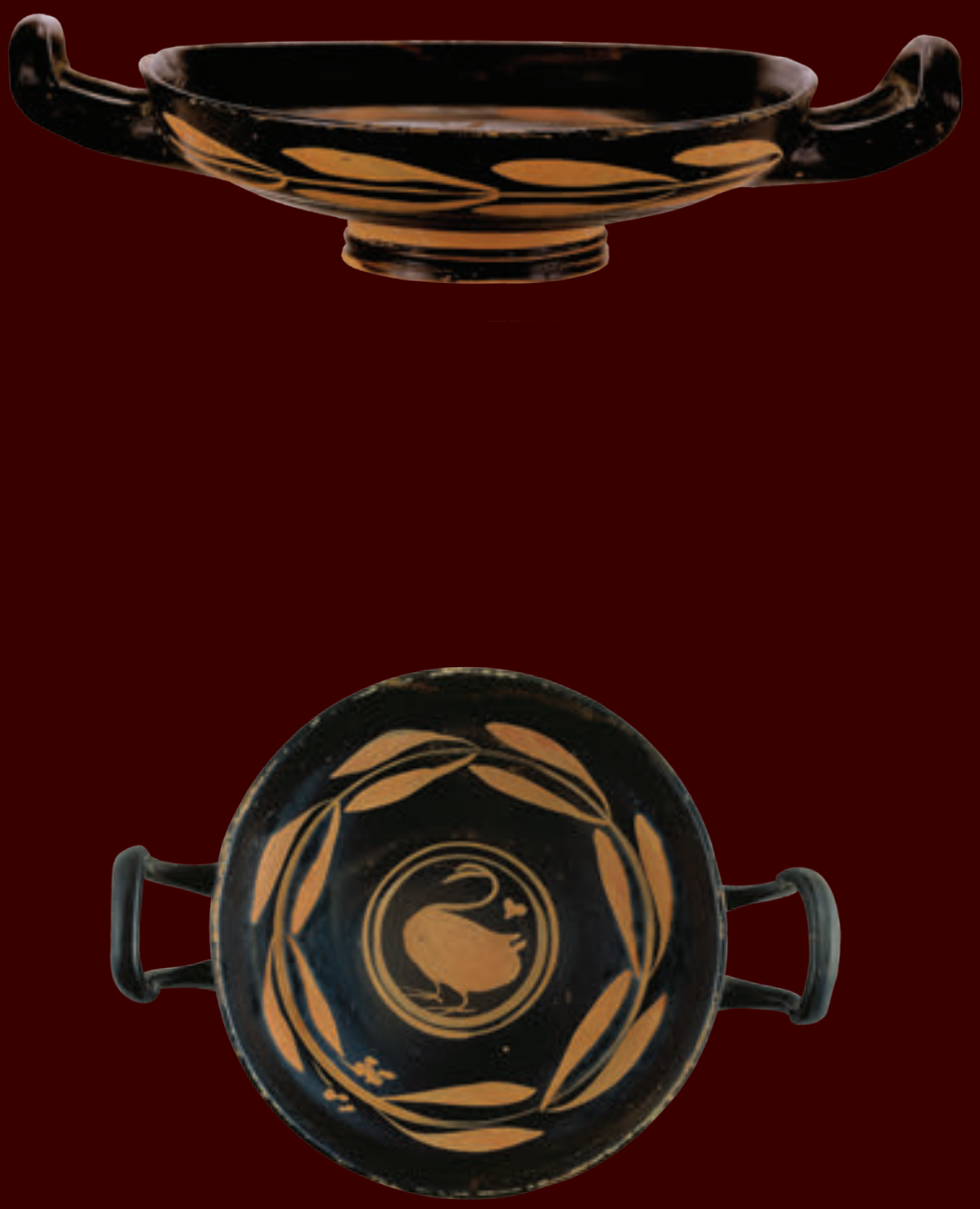

14.1 Diâm.: $15 \mathrm{~cm}$;

14.2 Alt.: $3,2 \mathrm{~cm}$

Diameter: $15 \mathrm{~cm}$;

Height: 3,2 cm 
Taça sem pé (Xenon Group) • Pintor do Cisne Rubro

Meados do século III a.C.

Taça inteiramente pintada a negro com motivos decorativos a vermelho. Na face externa, a toda a volta, coroa de folha de louro. O mesmo motivo no interior da taça que inclui, no centro, um cisne de perfil à esquerda delimitado por duas linhas concêntricas; à direita do cisne, folha de hera; dois rebentos florais simétricos na coroa de louros.

A atribuição à Apúlia, dada como incerta por Beazley (EVP 223), é atualmente aceite pela maioria dos investigadores (Mayo 1982: 304305, n. 160; Denoyelle e Iozzo 2009: 206 e fig. 288).

Na consulta do CVA encontram-se diversos exemplares afins, como: CVA Great Britain 10, Pl. 3, n..$^{\circ}$ a/b e 8; CVA Poland 5, Pl. 16, n. ${ }^{\circ}$ 1; CVA Deutchland 26, Taf. 61, n. 1 a 6; CVA Russia 3, Pl. 40, n. 1 e 3.

Publicado em: VGPortugal: 99.26.

Stemless Cup (Xenon Group) • The Red-Swan Painter

Mid-third century B.C.

Cup totally painted black with red decoration motifs. On the outer surface, a laurel leaf crown circles the piece entirely. The same motif on the inner surface of the cup, that includes, in the centre, a swan in profile, to the left, delineated by two concentric lines; to the right of the swan, ivy leaves; two symmetrical floral shoots on the laurel crown. The Apulian attribution of the piece, given as uncertain by Beazley (EVP 223), is now accepted by the majority of the researchers (Mayo 1982: 304-305, nr 160; Denoyelle and Iozzo 2009: 206 and fig. 288). When consulting the $C V A$, various similar specimens are found, such as: CVA Great Britain 10, Pl. 3, nr 2a/b and 8; CVA Poland 5, Pl. 16, nr 1; CVA Deutchland 26, Taf. 61, nr 1 to 6; CVA Russia 3, Pl. 40, nr 1 and 3. 

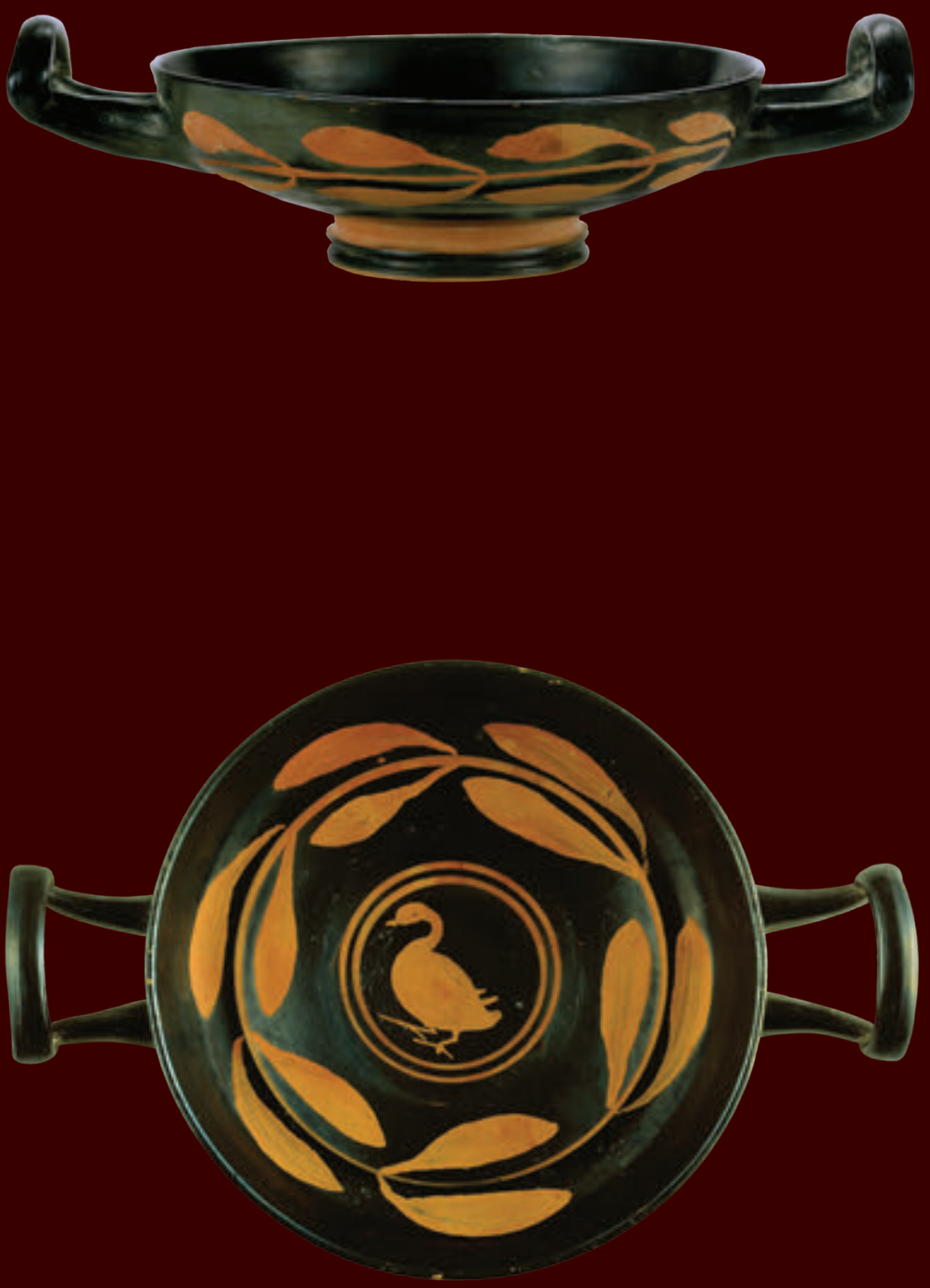

15.1 Diâm.: 15 cm;

15.2 Alt.: $4,2 \mathrm{~cm}$

Diameter: $15 \mathrm{~cm}$;

Height: 4,2 cm 
Taça sem pé (Xenon Group) • Pintor do Cisne Rubro Meados do século III a.C.

Taça idêntica à anterior e provavelmente oriunda da mesma oficina, apenas se diferenciando pela representação de um ganso como motivo central e sem a folha de hera e rebentos florais.

Publicado em: VGPortugal: 99.25.

Stemless Cup (Xenon Group) • The Red-Swan Painter

Mid-third century B.C.

Cup identical to the one described before, from the same workshop, differentiated only by the representation of a goose as its central motif and without the ivy leaf and floral shoots.

Published in: VGPortugal: 99.25. 



\section{BIBLIOGRAFIA / BIBLIOGRAPHY}

ABFV

$A B V$

ARFV II

$A R V$

Beazley Addenda

Beazley Archive

Burn 1987

Centeno 2015

CVA

Denoyelle e Iozzo 2009 M. Denoyelle e M. Iozzo - La Céramique Grecque d'Italie Méridionale et de Sicile. Productions Coloniales et Apparentées. Paris.

EVP

Ferreira 2008

Folsom 1975

Folsom 1976

Jesus 2008

Jesus 2012

Jesus e Duque 2012

Martelli 1987

Mayo 1982

Mintsi 1991

Morais 2008

Morais 2011

J. Boardman - Athenian Black-Figure Vases. London, Reimpr. 1980.

J. Beazley - Attic Black-Figure Vase-Painters. Oxford 1955.

J. Boardman - Athenian Red-Figure Vases: The Classical Period. London, Reimpr. 2012.

J. Beazley - Attic Red-Figure Vase-Painters. 3 volumes, $2^{\mathrm{a}}$ ed., Oxford 1963.

Burn, L. e Glynn, R. - Beazley Addenda: Additional References to AVB, ARV2 \& Paralipomena. Oxford 1982.

Disponível em: http://www.beazley.ox.ac.uk

L. Burn - The Meidias Painter. Oxford.

R.M.S. Centeno, Note on an Attic Hydria Attributed to the workshop of the Meidias Painter, Portugalia XXXVI (forthcoming).

Corpus Vasorum Antiquorum. Union Académique Internationale.

J.D. Beazley - Etruscan Vase-painting. Oxford 1947.

J.R. Ferreira - Rapto de Dejanira, in Morais 2008: 73-88.

R.S. Folsom - Attic Black-Figured Pottery. New Jersey.

R.S. Folsom - Attic Red-Figured Pottery. New Jersey.

C.A.M. Jesus - O crime de Dejanira ou a morte do herói (Baquílides, Dit. 16), in Morais 2008: 89-98.

C.A.M. Jesus - Dois vasos gregos inéditos, in Jesus e Duque 2012: 30-45.

C.A.M. Jesus e J.M.V. Duque - Vasos gregos e pintura de tema clássico no Museu da Fundação Dionísio Pinheiro e Alice Cardoso Pinheiro. (Col. Classica Instrumenta). Coimbra.

M. Martelli - La ceramica etrusco-corinzia, in M. Martelli (a cura di), La ceramica degli etruschi. La pittura vascolare. Novara - 1987: 269-296.

M.E. Mayo (Ed.) - The Art of South Italy: Vases from Magna Graecia. Richmond.

E. Minsty - Hypnos et Thanatos sur les vases attiques (520-470 av. J. C.), Histoire de l'Art 15, Paris, Septembre 1991:9-20.

R. Morais - A colecção de lucernas romanas do Norte de África no Museu D. Diogo de Sousa. (Col. Fluir Perene, 7). Coimbra.

R. Morais - A colecção de vasos gregos do Museu de Farmácia. (Col. Classica Instrumenta). Coimbra. 
Morais e Centeno 2013 R. Morais e R. Centeno - Notícia sobre quatro vasos áticos da coleção D. Manuel de Lancastre. Portugalia XXXIV: 69-81.

Olmos 1993

Paralipomena

Richter 1946

RVAP

RVSIS

Szilágyi 1986

Szilágyi 1992

VGPortugal

VVAA 1992
R. Olmos - Catálogo de los vasos griegos del Museo Nacional de Bellas Artes de La Habana. Madrid.

J. Beazley - Paralipomena: Additions to Attic Black-Figure Vase-Painters and to Attic Red-Figure Vase-Painters. Oxford 1971.

G.M.A. Richter - Attic Red-Figured Vases. A Survey. New Haven.

I A.D. Trendall e A. Cambitoglou - The Red-figured Vases of Apulia: I. Early and Middle Apulian. Oxford 1978.

A.D. Trendall - Red Figure Vases of South Italy and Sicily. London 1989

J.Gy. Szilágyi - Etrusko-korinthische Vasen in Malibu, in Greek Vases in the Paul Getty Museum. (Col. Occasional Papers on Antiquities, 2). Malibu: 1-16.

J.Gy. Szilágyi - Ceramica etrusco-corinzia figurata. Parte I, 630-580 a.C. (Monumenti Etruschi, 7). Firenze.

M.H. Rocha Pereira (Coord.) - Vasos gregos em Portugal. Aquém das colunas de Hércules. Lisboa 2007.

La collezione archeologica del Banco di Sicilia. 2 vols. Palermo. 


\section{LISTA DAS FIGURAS}

COLEÇÃO D. MANUEL LANCASTRE

(Fotografias de José Pessoa, salvo $n^{\circ}$. 7.2)

1. Olpe com aletas circulares, etrusco-coríntio.

2. Olpe com aletas circulares, etrusco-coríntio.

3.1-2. Taça de tipo B, Pintor de Lancastre.

4.1-2. Taça de tipo B, Pintor de Oltos.

5. Taça de tipo C, Cup Little Master Band.

6.1-2. Ânfora de Colo, à maneira do Pintor de Antimenes.

7.1. Skyphos, Heron Class.

7.2. Skyphos, Heron Class, Fotografia do catálogo, Christie's, Sale 9088, London, SK, 25 April 2001, Lote 161.

8.1-4. Taça, Grupo de Pezzino.

\section{LIST OF FIGURES}

\section{MANUEL LANCASTRE COLLECTION}

(Photographs by José Pessoa, except nr. 7.2)

1. Olpe with rotelles, Etrusco-Corinthian.

2. Olpe with rotelles, Etrusco-Corinthian.

3.1-2. Type B Cup, Lancastre Painter.

4.1-2. Type B Cup, Oltos Painter.

5. Type C Cup, Little-Master Band.

6.1-2. Neck-Amphora, in the manner of the Antimenes Painter.

7.1. Skyphos, Heron Class.

7.2. Skyphos, Heron Class, Photograph in auction catalogue,

Christie's, Sale 9088, London, SK, 25 April 2001, Lot 161.

8.1-4. Cup, Pezzino Group. 
9.1-4. Taça, Pintor de Villa Giulia.

10.1-2. Lêkythos, Pintor de Bowdoin.

11.1-2. Hýdria, à maneira do Pintor de Meidias.

12.1-3. Kratêr-de-sino, Pintor de Dijon.

13.1-2. Chous, Pintor de Reckoning.

14.1-2. Taça sem pé (Xenon Group), Pintor do Cisne Rubro.

15.1-2. Taça sem pé (Xenon Group), Pintor do Cisne Rubro.

9.1-4. Cup, Villa Giulia Painter.

10.1-2. Lekythos, Bowdoin Painter.

11.1-2. Hydria, in the manner of the Meidias Painter.

12.1-3. Bell-Krater, Dijon Painter.

13.1-2. Chous, Reckoning Painter.

14.1-2. Stemless Cup (Xenon Group), The Red-swan Painter.

15.1-2. Stemless Cup (Xenon Group), The Red-swan Painter. 


\section{COLEÇÕES DE MUSEUS}

(Fotografias cedidas e autorizadas pelos respetivos museus)

3a-c Taça de tipo B, Pintor de Lancastre. Lindenau-Museum Altenburg, 227.

4a-b Taça de tipo B, Pintor de Oltos. Ashmolean Museum, Oxford, G. 265.

6a-b Ânfora de Colo, à maneira do Pintor de Antimenes. Staatliche Antikensammlungen und Glyptothek, München, 1576.

$7 \mathrm{a}$ Skyphos, Heron Class. The Metropolitan Museum, New York, 41.162.125.

9a-c Taça, Pintor de Villa Giulia. Antikensammlung, Staatliche Museen, Berlin, 2522.

11a Hýdria, à maneira do Pintor de Meidias. Catálogo de leilão, Bonhams, London, 28 April 2010, Lote 182.

\section{MUSEUMS COLLECTIONS}

(Photographs reproduced with permission)

3a-c Type B Cup, Lancastre Painter. Lindenau-Museum Altenburg, 227. 4a-b Type B Cup. Oltos Painter. Ashmolean Museum, Oxford, G. 265. 6a-b Neck-Amphora, in the manner of the Antimenes Painter. Staatliche Antikensammlungen und Glyptothek, München, 1576.

7a Skyphos, Heron Class. The Metropolitan Museum, New York, 41.162 .125 .

9a-c Cup, Villa Giulia Painter. Antikensammlung, Staatliche Museen, Berlin, 2522

11a Hydria, in the manner of the Meidias Painter. Auction catalogue, Bonhams, London, 28 April 2010, Lot 182. 
(Página deixada propositadamente em branco) 



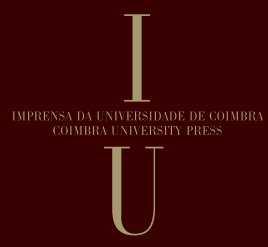

OBRA PUBLICADA

COM A COORDENAÇÃO

CIENTÍFICA

$\mathrm{ECH}$

- U

C • 